\title{
Conformational isomers from rotation of diacetylenic bond in an ethynylpyrene substituted molecular hinge
}

\author{
Sethuraman Sankararaman, ${ }^{\mathrm{a}}$ Gandikota Venkataramana, ${ }^{\mathrm{a}}$ and Babu Varghese ${ }^{\mathrm{b}}$ \\ ${ }^{a}$ Department of Chemistry and ${ }^{b}$ Sophisticated Analytical Instrument Facility, Indian Institute of \\ Technology Madras, Chennai 600036, India
}

\section{Contents:}

Page

$\begin{array}{ll}\text { 1. Synthetic Scheme for target } 1 & \text { S2 }\end{array}$

2. Experimental procedure and characterization data for 1, 2, 4-6 S2-S5

3. Figure 1, UV-Vis absorption spectra of $\mathbf{1}$ and $\mathbf{2}$ S6

$\begin{array}{lll}\text { 4. } & \text { Figure 2, Fluorescence spectra of } \mathbf{1} \text { and } \mathbf{2} & \text { S7 }\end{array}$

5. Figure 3, Fluorescence spectra of $\mathbf{1}$ as a function of concentration S8

6. Figure 4, Fluorescence spectra of $\mathbf{1}$ as a function of excitation wavelength S9

7. Figure 5, Structure of $\mathbf{1 a}$ and $\mathbf{1 b}$ in the crystal S10

8. Figure 6, Structure of $\mathbf{1 b}$ in the crystal S11

$\begin{array}{lll}\text { 9. } & \text { Figure 7, Structure of 1a in the crystal } & \text { S12 }\end{array}$

10. Figure 8, Packing diagram of $\mathbf{1 b}$ in the crystal S13

11. Figure 9, Packing diagram of $\mathbf{1 b}$ in the crystal S13

12. Figure 10, Packing diagram of 1a in the crystal S14

13. Crystallographic data for 1a $\quad$ S15

14. Crystallographic data for $\mathbf{1 b} \quad$ S16

15. Figure 11 to $30,{ }^{1} \mathrm{H}$ and ${ }^{13} \mathrm{C}$ NMR spectra of 1, 2, 4-6 S17-S36

16. Figure 31, Absorption and fluorescence spectra of $\mathbf{1}$ in thin film S37

17. Figure 32, Absorption spectra of $\mathbf{1}$ at various temperatures S38

18. Figure 33, Fluorescence spectra of $\mathbf{1}$ at various temperatures $\quad$ S39 
Synthesis of 1 was carried out according to Scheme 1.
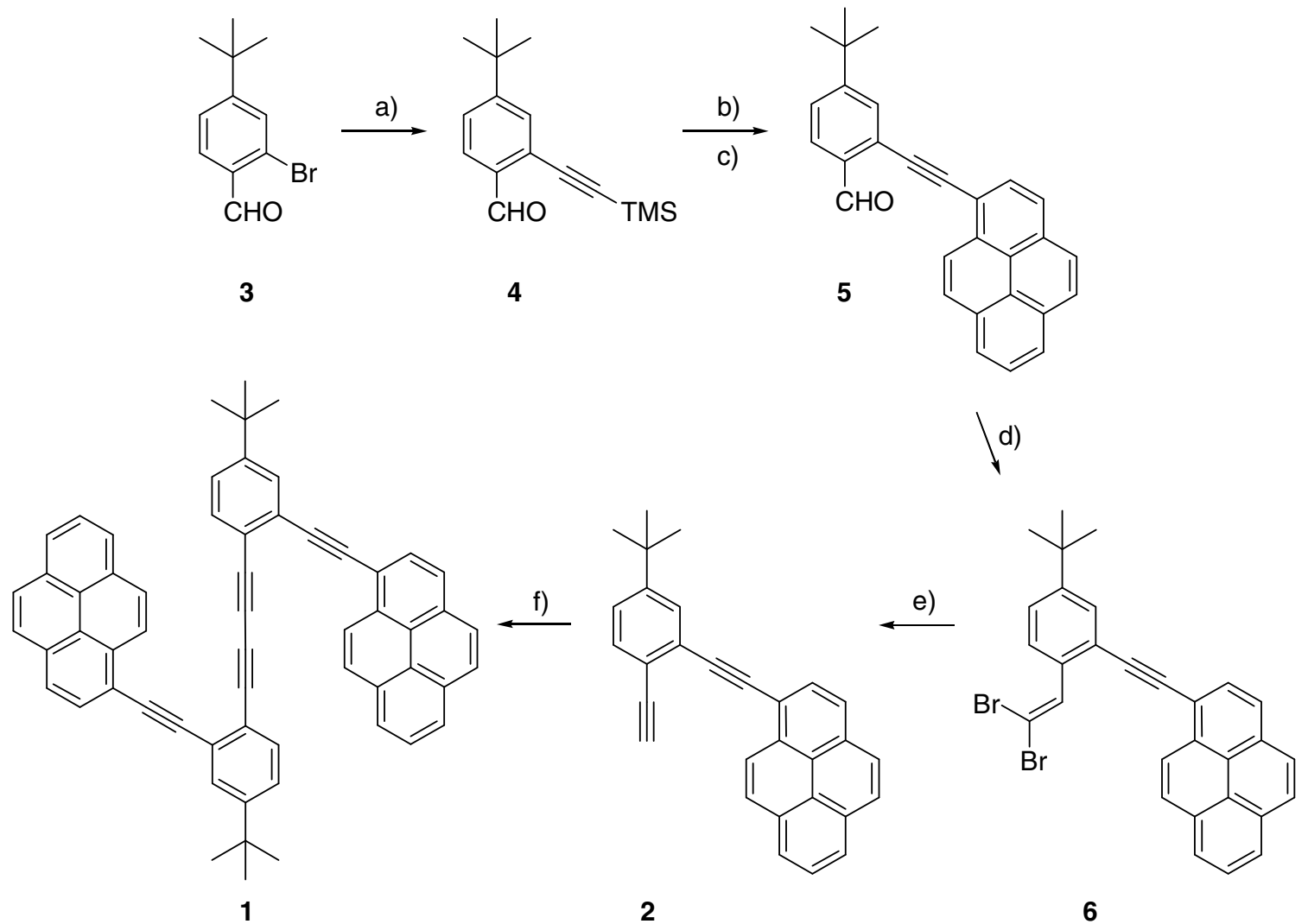

Scheme 1. Synthesis of 1. Reagents and conditions: a) trimethylsilylacetylene, $\mathrm{Pd}\left(\mathrm{PPh}_{3}\right)_{2} \mathrm{Cl}_{2}, \mathrm{PPh}_{3}, \mathrm{CuI}, \mathrm{Et}_{3} \mathrm{~N}, 60{ }^{\circ} \mathrm{C}, 6$ h, $85 \%$; b) $\mathrm{K}_{2} \mathrm{CO}_{3}, \mathrm{MeOH}, \mathrm{rt}, 3 \mathrm{~h}, 90 \%$; c) $1-$ iodopyrene, $\mathrm{Pd}\left(\mathrm{PPh}_{3}\right)_{4}, \mathrm{PPh}_{3}, \mathrm{CuI}, \mathrm{Et}_{3} \mathrm{~N}, 60{ }^{\circ} \mathrm{C}, 7 \mathrm{~h}, 86 \%$; d) $\mathrm{CBr}_{4}, \mathrm{PPh}_{3}, \mathrm{Zn}, \mathrm{DCM}, 0{ }^{\circ} \mathrm{C}$ to $\mathrm{rt}, 8 \mathrm{~h}, 95 \%$; e) LDA, THF, $-78{ }^{\circ} \mathrm{C}, 1 \mathrm{~h}$; f) $\mathrm{Cu}(\mathrm{OAc})_{2} \cdot \mathrm{H}_{2} \mathrm{O}$, acetonitrile/pyridine $(4: 1$ v/v), rt, 4 h, $71 \%$.

All the reactions were carried out under dry $\mathrm{N}_{2}$ atmosphere unless otherwise stated.

4-t-Butyl-2-trimethylsilylethynylbenzaldehyde (4): A schlenk flask was charged with 2-bromo-4- $t$-butylbenzaldehyde $(3)^{1}(2.0 \mathrm{~g}, 8.3 \mathrm{mmol}), \mathrm{Pd}\left(\mathrm{PPh}_{3}\right)_{2} \mathrm{Cl}_{2}(0.116 \mathrm{~g}, 0.16$ $\mathrm{mmol}), \mathrm{PPh}_{3}(0.086 \mathrm{~g}, 0.33 \mathrm{mmol}), \mathrm{CuI}(0.063 \mathrm{~g}, 0.33 \mathrm{mmol})$ and $\operatorname{degassed~}^{\mathrm{Et}} \mathrm{N}_{3} \mathrm{~N}(70 \mathrm{ml})$. The mixture was stirred at $\mathrm{rt}$ for $15 \mathrm{~min}$. Trimethysilylacetylene $(0.975 \mathrm{~g}, 9.96 \mathrm{mmol})$ was added and stirring was continued at $60^{\circ} \mathrm{C}$ for $6 \mathrm{~h}$. The reaction mixture was cooled to $\mathrm{rt}$ and filtered. The filtrate was neutralized with $5 \%$ aqueous $\mathrm{HCl}$ and extracted with $\mathrm{CH}_{2} \mathrm{Cl}_{2}(20 \mathrm{ml})$. The organic layer was washed with water $(2 \times 30 \mathrm{ml})$ and dried over $\mathrm{Na}_{2} \mathrm{SO}_{4}$. Removal of solvent under reduced pressure at $\mathrm{rt}$ gave the crude product. The crude product was purified by column chromatography on silica gel using $\mathrm{CH}_{2} \mathrm{Cl}_{2}$-hexane 
(5: $95 \mathrm{v} / \mathrm{v})$ to give $4(1.82 \mathrm{~g}, 85 \%)$ as a pale yellow liquid. IR (KBr): 2860, 2156, 1694 $\mathrm{cm}^{-1} ;{ }^{1} \mathrm{H}$ NMR $\left(400 \mathrm{MHz}, \mathrm{CDCl}_{3}\right): \delta 10.49(\mathrm{~s}, 1 \mathrm{H}), 7.84(\mathrm{~d}, J=8.3 \mathrm{~Hz}, 1 \mathrm{H}), 7.55(\mathrm{~d}, J=$ $1.9 \mathrm{~Hz}, 1 \mathrm{H}), 7.46(\mathrm{dd}, J=8.3$ and $1.9 \mathrm{~Hz}, 1 \mathrm{H}), 1.33$ (s, 9H), 0.28 (s, 9H) ppm; ${ }^{13} \mathrm{C}$ NMR (100 MHz, $\left.\mathrm{CDCl}_{3}\right): \delta$ 192.0, 158.0, 134.2, 130.7, 127.1, 126.9, 126.7, 101.8, 101.0, 35.6, 31.2, 0.2 ppm; MS (ESI): $\mathrm{m} / z$ (\%) 259 (10) $\left[\mathrm{M}+\mathrm{H}^{+}\right], 226$ (25); HRMS: calcd. for $\mathrm{C}_{16} \mathrm{H}_{23} \mathrm{OSi} 259.1518$, found 259.1527 .

4-t-Butyl-2-(1-pyrenylethynyl)benzaldehyde (5): A schlenk flask was charged with 4 $(2.0 \mathrm{~g}, 7.75 \mathrm{mmol}), \mathrm{K}_{2} \mathrm{CO}_{3}(2.14 \mathrm{~g}, 15.5 \mathrm{mmol})$ and methanol $(70 \mathrm{ml})$. The mixture was stirred at room temperature for $3 \mathrm{~h}$. Upon completion of the reaction, $\mathrm{K}_{2} \mathrm{CO}_{3}$ was filtered off and solvent was evaporated at $\mathrm{rt}$ under reduced pressure to yield 4-t-butyl-2ethynylbenzaldehyde (1.3 g, $90 \%)$ as a colorless liquid. It was immediately used further without purification. A schlenk flask was charged with 1-iodopyrene ${ }^{2}(1.0 \mathrm{~g}, 3.05 \mathrm{mmol})$, $\mathrm{Pd}\left(\mathrm{PPh}_{3}\right)_{4}(0.07 \mathrm{~g}, 0.06 \mathrm{mmol})$, CuI (0.023 g, $\left.0.12 \mathrm{mmol}\right)$ and degassed $\mathrm{Et}_{3} \mathrm{~N}(40 \mathrm{ml})$. The mixture was stirred at room temperature for $15 \mathrm{~min}$ and then the crude 4-t-butyl-2ethynylbenzaldehyde $(0.680 \mathrm{~g}, 3.658 \mathrm{mmol})$ was added, Stirring was continued at $60{ }^{\circ} \mathrm{C}$ for $7 \mathrm{~h}$. The reaction mixture was cooled to rt and filtered. The filtrate was neutralized with $5 \%$ aqueous $\mathrm{HCl}$ and extracted with $\mathrm{CH}_{2} \mathrm{Cl}_{2}(20 \mathrm{ml})$. The organic layer was washed with water $(2 \times 30 \mathrm{ml})$ and dried over $\mathrm{Na}_{2} \mathrm{SO}_{4}$. Solvent was removed at $\mathrm{rt}$ under reduced pressure. The crude product was purified by column chromatography on silica gel using $\mathrm{CH}_{2} \mathrm{Cl}_{2}$-hexane (5:95 v/v) to yield 5 as a pale yellow solid (1.01 g, $86 \%$ ), mp 132-135 ${ }^{\circ} \mathrm{C}$. IR (KBr): 2954, 2193, $1683 \mathrm{~cm}^{-1} ;{ }^{1} \mathrm{H}$ NMR $\left(400 \mathrm{MHz}, \mathrm{CDCl}_{3}\right): \delta 10.73(\mathrm{~s}, 1 \mathrm{H}), 8.55$ (d, $J=9.3 \mathrm{~Hz}, 1 \mathrm{H}), 8.17-7.94(\mathrm{~m}, 8 \mathrm{H}), 7.88(\mathrm{~d}, J=8.3 \mathrm{~Hz}, 1 \mathrm{H}), 7.74(\mathrm{~d}, J=1.9 \mathrm{~Hz}, 1 \mathrm{H})$, $7.46(\mathrm{dd}, J=8.3,1.9 \mathrm{~Hz}, 1 \mathrm{H}), 1,34(\mathrm{~s}, 9 \mathrm{H}) \mathrm{ppm} ;{ }^{13} \mathrm{C} \mathrm{NMR}\left(100 \mathrm{MHz}, \mathrm{CDCl}_{3}\right): \delta 191.4$, 157.8, 133.6, 132.0, 131.7, 131.1, 130.9, 130.3, 129.8, 128.7, 128.5, 127.6, 127.1, 126.8, $126.3,126.2,125.9,125.8,125.2,124.5,124.4,124.2,116.8,94.9,91.2,35.3,31.0$ ppm; MS (EI, $70 \mathrm{eV}): m / z(\%) 387(33), 386\left(100, \mathrm{M}^{+}\right), 371$ (32).

4-t-Butyl-2-(1-pyrenylethynyl)- $\beta, \beta$-dibromostyrene (6): To a dichloromethane $(50 \mathrm{ml})$ solution of $\mathrm{PPh}_{3}(2.72 \mathrm{~g}, 10.36 \mathrm{mmol})$ zinc powder $(0.67 \mathrm{~g}, 10.36 \mathrm{mmol})$ was added and then cooled to $0{ }^{\circ} \mathrm{C}$. $\mathrm{CBr}_{4}(3.44 \mathrm{~g}, 10.36 \mathrm{mmol})$ was added in small portions over $30 \mathrm{~min}$. The reaction mixture was brought to room temperature and stirring was continued for $1 \mathrm{~h}$. The reaction mixture was cooled to $0{ }^{\circ} \mathrm{C}$ and $\mathbf{5}(0.5 \mathrm{~g}, 1.3 \mathrm{mmol})$ was added in small 
portions over $30 \mathrm{~min}$. The mixture was stirred at $\mathrm{rt}$ for $8 \mathrm{~h}$. It was filtered and solvent was evaporated to dryness at $\mathrm{rt}$ under reduced pressure. The crude product was purified by column chromatography on a silica gel using hexane as the eluant to yield dibromide $\mathbf{6}$ as a pale yellow solid $(0.67 \mathrm{~g}, 95 \%), \mathrm{mp} 144-147{ }^{\circ} \mathrm{C}$. IR (KBr): $2946,2230 \mathrm{~cm}^{-1} ;{ }^{1} \mathrm{H}$ NMR (400 MHz, CDCl $): \delta 8.55(\mathrm{~d}, J=8.8 \mathrm{~Hz}, 1 \mathrm{H}), 8.15-7.91(\mathrm{~m}, 9 \mathrm{H}), 7.71(\mathrm{~d}, J=8.3$ $\mathrm{Hz}, 1 \mathrm{H}), 7.65$ (d, $J=1.9 \mathrm{~Hz}, 1 \mathrm{H}), 7.34$ (dd, $J=8.3$ and $1.9 \mathrm{~Hz}, 1 \mathrm{H}), 1.31$ (s, 9H) ppm; ${ }^{13} \mathrm{C}$ NMR $\left(100 \mathrm{MHz}, \mathrm{CDCl}_{3}\right): \delta 151.9,136.3,134.7,132.2,131.7,131.5,131.3,129.9$, 129.3, 129.0, 128.6, 128.1, 127.5, 126.5, 126.0, 125.9, 125.8, 124.8, 124.7, 124.5, 123.0, 117.7, 94.1, 93.8, 91.3, 35.1, 31.4 ppm; MS (EI, $70 \mathrm{eV}): \mathrm{m} / \mathrm{z}$ (\%) 544 (10), 542 (20), 540(10) $\left[\mathrm{M}^{+}\right]$(for $\mathrm{C}_{30} \mathrm{H}_{22} \mathrm{Br}_{2}$ ) (isotope peaks in the ratio 1:2:1), 463 (48), 461 (48) [M $\mathrm{Br}$ ] (isotope peaks), 382 [M - 2Br], 367, 326 (100).

1-(5-t-butyl-2-ethynylphenylthynyl)pyrene (2): An oven dried schlenk flask was charged with $6(0.4 \mathrm{~g}, 0.74 \mathrm{mmol})$ and dry THF $(30 \mathrm{ml})$. It was cooled to $-78^{\circ} \mathrm{C}$. LDA (2.95 mmol) [freshly prepared from $2.95 \mathrm{mmol}$ each of $n$-BuLi $(1.83 \mathrm{ml}$ of $1.6 \mathrm{M}$ solution in hexane) and diisopropyl amine $(0.4 \mathrm{ml})$ at $-78{ }^{\circ} \mathrm{C}$ in THF] was added and stirring continued for $1 \mathrm{~h}$. Upon completion of the reaction it was quenched with saturated $\mathrm{NH}_{4} \mathrm{Cl}$ at $-78{ }^{\circ} \mathrm{C}$. The reaction mixture was extracted with $\mathrm{CH}_{2} \mathrm{Cl}_{2}(30 \mathrm{ml})$. The organic layer was washed with water $(2 \mathrm{x} 40 \mathrm{ml})$ and dried over $\mathrm{Na}_{2} \mathrm{SO}_{4}$. Solvent was evaporated to dryness at $\mathrm{rt}$ under reduced pressure. The crude product was purified by column chromatography on silica gel using hexane as eluant to yield $\mathbf{1}$ as a pale yellow solid (0.20 g, 71\%), mp 85-87 ${ }^{\circ} \mathrm{C}$; IR (KBr): 2950, $2189 \mathrm{~cm}^{-1} ;{ }^{1} \mathrm{H}$ NMR (400 MHz, $\left.\mathrm{CDCl}_{3}\right): \delta 8.99(\mathrm{~d}, J=9.3 \mathrm{~Hz}, 1 \mathrm{H}), 8.34-8.06(\mathrm{~m}, 8 \mathrm{H}), 7.87(\mathrm{~d}, J=1.9 \mathrm{~Hz}, 1 \mathrm{H}), 7.67(\mathrm{~d}, J$ $=8.3 \mathrm{~Hz}, 1 \mathrm{H}), 7.48(\mathrm{dd}, J=8.3,1.9 \mathrm{~Hz}, 1 \mathrm{H}), 3.62(\mathrm{~s}, 1 \mathrm{H}), 1.48(\mathrm{~s}, 9 \mathrm{H}) \mathrm{ppm} ;{ }^{13} \mathrm{C} \mathrm{NMR}$ $\left(100 \mathrm{MHz}, \mathrm{CDCl}_{3}\right): \delta 152.0,132.5,132.0,131.2,131.1,130.9,129.6,128.8,128.1$, 127.1, 126.2, 126.1, 125.9, 125.5, 124.4, 124.4, 124.3, 124.1, 121.6, 117.7, 94.0, 92.2, 83.0, 80.6, 34.8, 31.0 ppm; MS (EI, $70 \mathrm{eV}): m / z(\%)=383\left(30,382\left(100, \mathrm{M}^{+}\right), 326(25)\right.$, 170 (95). HRMS: calcd. for $\mathrm{C}_{30} \mathrm{H}_{22} 382.17215$; found 382.17165 .

1: $\mathrm{Cu}(\mathrm{OAc})_{2} \cdot \mathrm{H}_{2} \mathrm{O}(0.163 \mathrm{~g}, 0.82 \mathrm{mmol})$ was dissolved in a mixture of acetonitrile $(12 \mathrm{ml})$ and pyridine ( $3 \mathrm{ml})$ and $2(0.125 \mathrm{~g}, 0.327 \mathrm{mmol})$ was added. Reaction mixture was stirred at $\mathrm{rt}$ for $4 \mathrm{~h}$. It was neutralized with $5 \% \mathrm{HCl}$ and extracted with $\mathrm{CH}_{2} \mathrm{Cl}_{2}(25 \mathrm{ml})$. The organic layer was washed with water $(30 \mathrm{ml})$, dried over $\mathrm{Na}_{2} \mathrm{SO}_{4}$ and solvent was 
evaporated at $\mathrm{rt}$ under reduced pressure to dryness. The crude product was purified by column chromatography on silica gel using hexane as an eluant to yield the dimer (1) as a yellow solid (0.106 g, $85 \%$ ). Temperature for onset of decomposition: $255-259{ }^{\circ} \mathrm{C}$; IR (KBr): 2957, $2196 \mathrm{~cm}^{-1} ;{ }^{1} \mathrm{H}$ NMR (400 MHz, $\left.\mathrm{CDCl}_{3}\right): \delta 8.55(\mathrm{~d}, J=9.2 \mathrm{~Hz}, 2 \mathrm{H}), 8.0(\mathrm{~d}$, $J=8.8 \mathrm{~Hz}, 2 \mathrm{H}), 7.80-7.95(\mathrm{~m}, 6 \mathrm{H}), 7.70(\mathrm{~m}, 4 \mathrm{H}), 7.61(\mathrm{~d}, J=7.8 \mathrm{~Hz}, 2 \mathrm{H}), 7.46(\mathrm{~d}, J=$ $8.8 \mathrm{~Hz}, 2 \mathrm{H}), 7.35-7.40(\mathrm{~m}, 4 \mathrm{H}), 7.27$ (d, $J=8.3 \mathrm{~Hz}, 2 \mathrm{H}), 1.37$ (s, 18H) ppm; ${ }^{13} \mathrm{C}$ NMR $\left(100 \mathrm{MHz}, \mathrm{CDCl}_{3}\right): \delta 152.6,133.0,131.4,130.9,130.8,130.3,128.8,128.6,128.5$, 127.3, 126.7, 125.6, 125.4, 124.7, 123.5, 123.4, 123.1, 121.5, 116.7, 93.6, 93.4, 82.4, 78.0, 35.0, $31.1 \mathrm{ppm}$; MS (EI, $70 \mathrm{eV}): \mathrm{m} / \mathrm{z}(\%)=762\left(100, \mathrm{M}^{+}\right)$; HRMS: calcd. for $\mathrm{C}_{60} \mathrm{H}_{42}$ 762.32865; found 762.32740.

\section{References.}

(1) Mallory, F. B.; Butler, K. E.; Berube, A.; Luzik, E. D.; Mallory, C. W.; Brondyke, E. J.; Hiremath, R.; Ngo, P.; Carroll, P. J. Tetrahedron, 2001, 57(17), 3715-3724. (2) Rivera1, E.; Bellete^te, M.; Zhu, X. X.; Durocher, G.; Giasson, R. Polymer, 2002, 43, 5059-5068. 


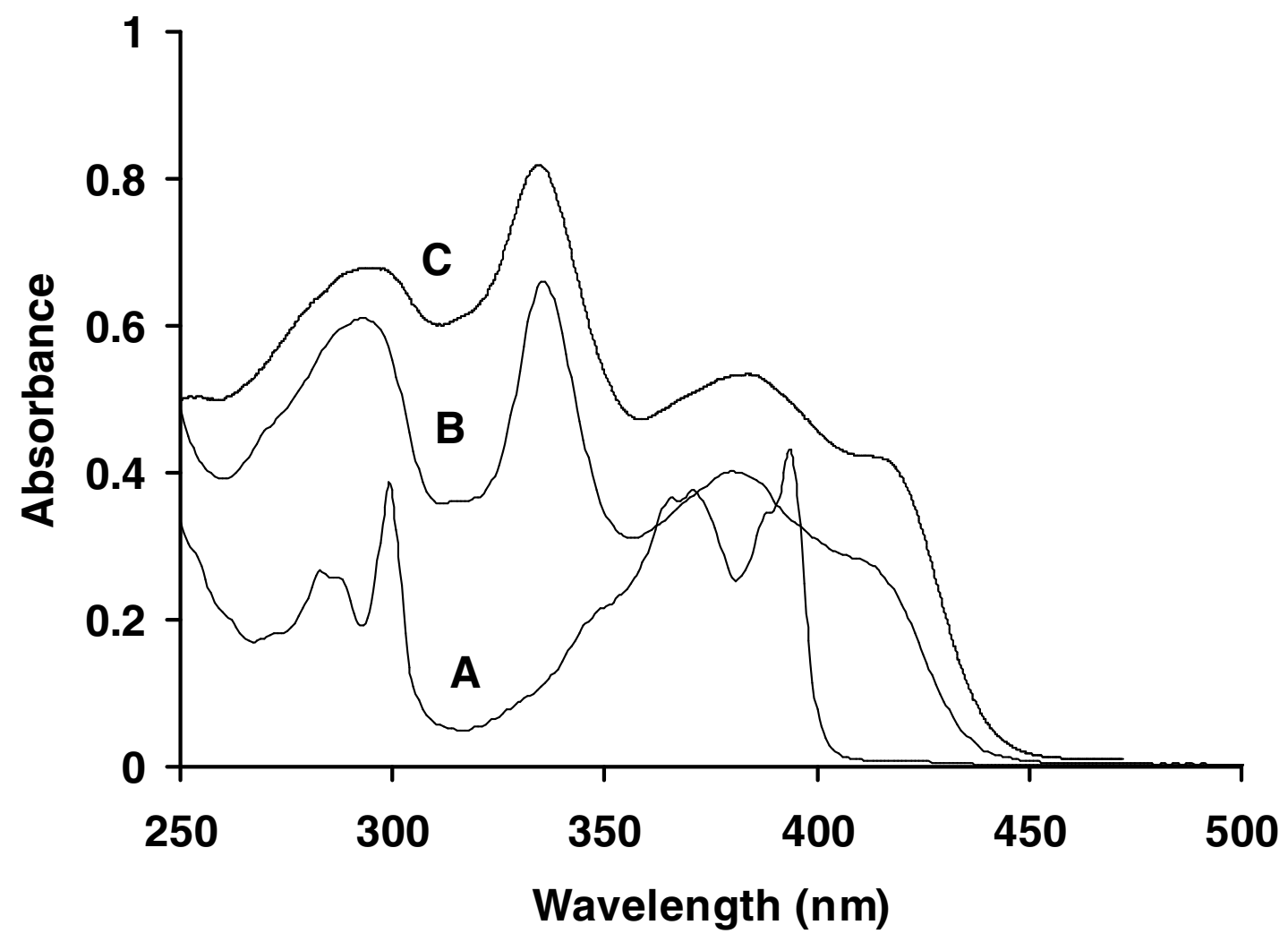

Figure 1. Absorption spectra of 2 (A) and 1 (B) in cyclohexane $\left(1 \times 10^{-5} \mathrm{M}\right)$ and excitation spectrum of $\mathbf{1}(\mathrm{C})\left(\lambda_{\mathrm{em}} 483 \mathrm{~nm}\right)$ in cyclohexane with arbitrary Y-axis. 


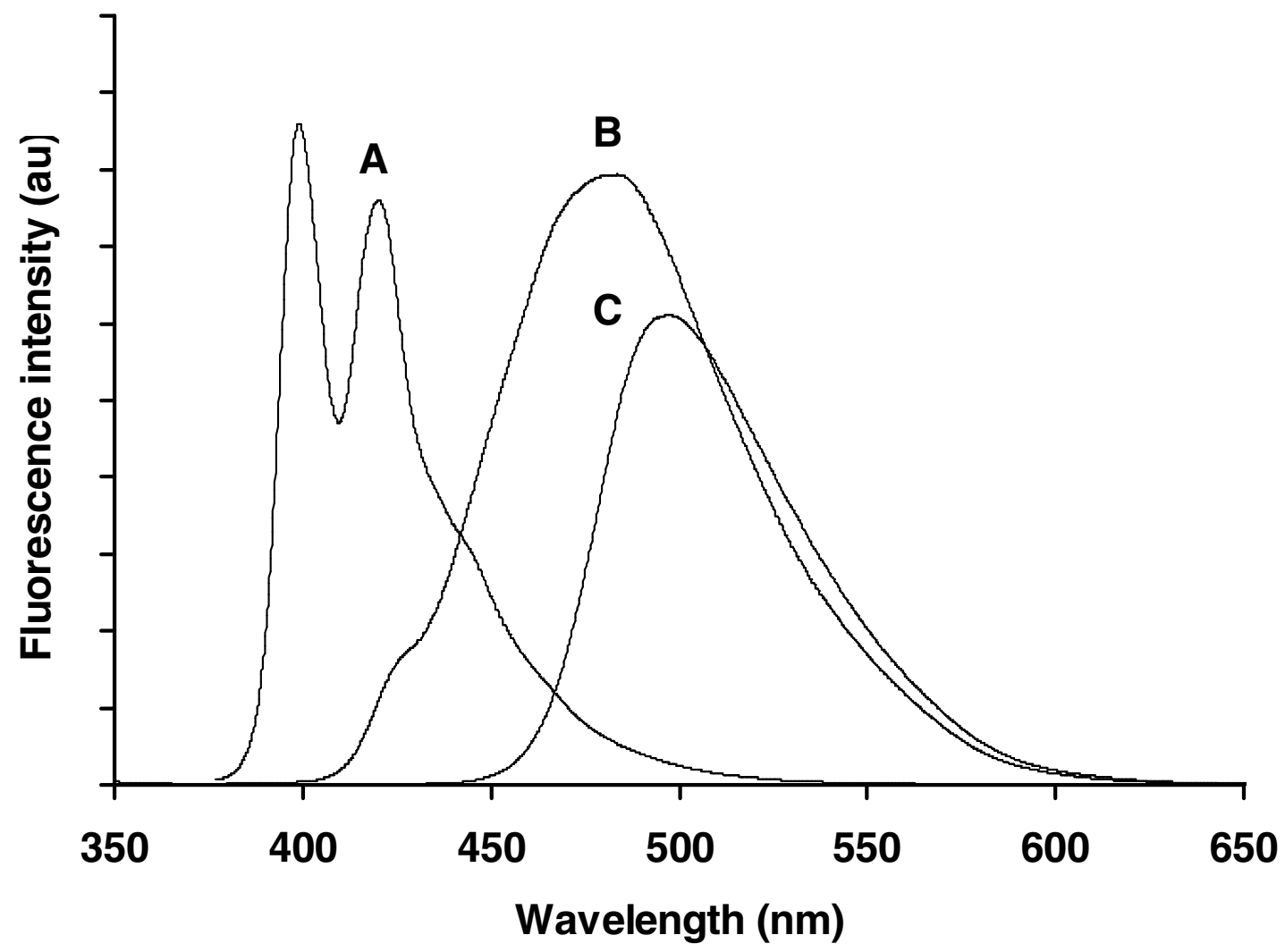

Figure 2. Fluorescence emission spectra of $2\left(A, \lambda_{\text {ex }} 367 \mathrm{~nm}\right)$ and $\mathbf{1}\left(B, \lambda_{\text {ex }} 333 \mathrm{~nm}\right)$ in cyclohexane $\left(1 \times 10^{-5} \mathrm{M}\right)$ and of $\mathbf{1}$ in solid state $\left(\mathrm{C}, \lambda_{\mathrm{ex}} 333 \mathrm{~nm}\right)$. 


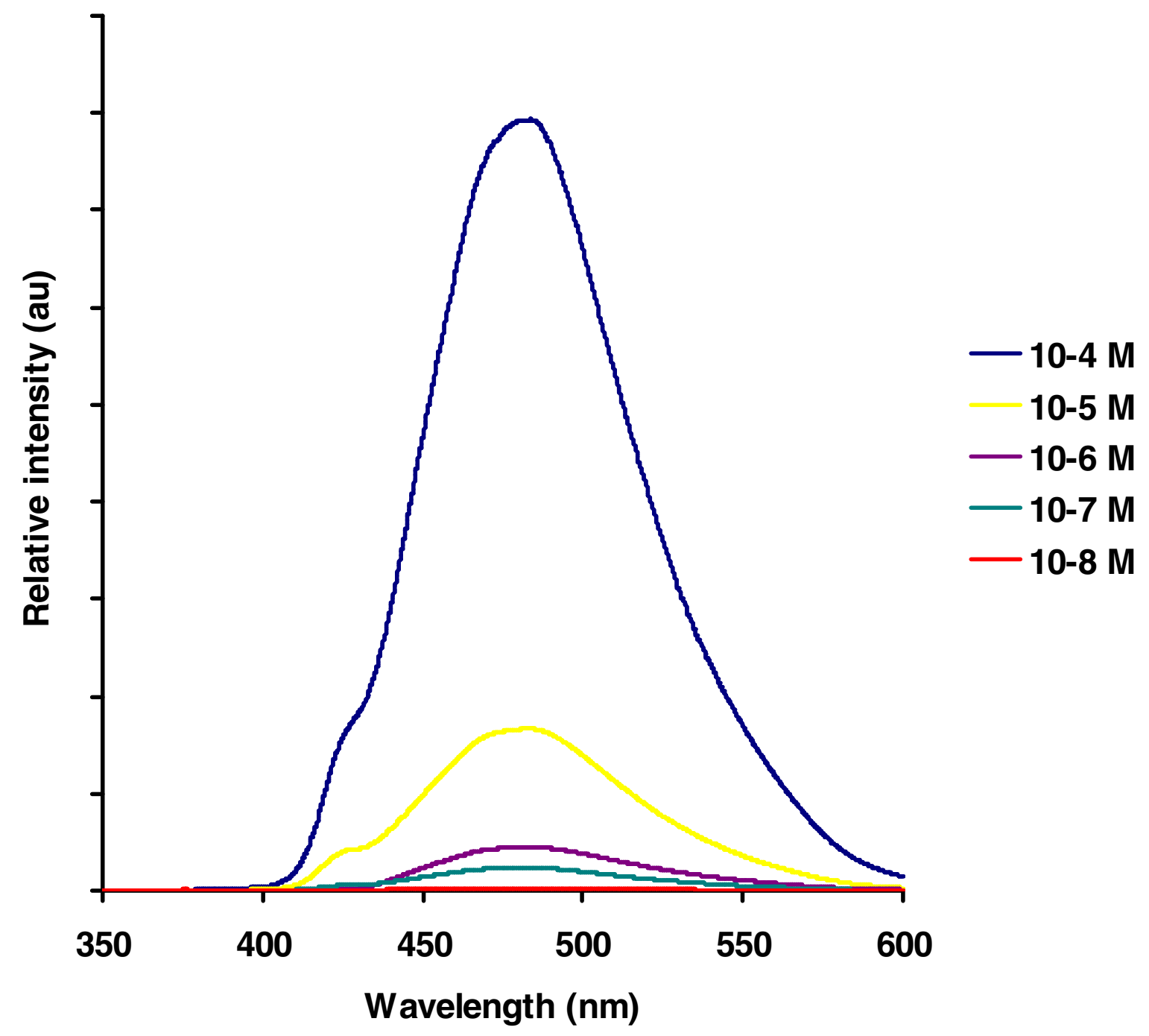

Figure 3. Fluorescence emission spectra of 1 at different concentrations $\left(10^{-4}\right.$ to $\left.10^{-8} \mathrm{M}\right)$ in cyclohexane. $\left(\lambda_{\mathrm{ex}} 336 \mathrm{~nm}\right)$. 


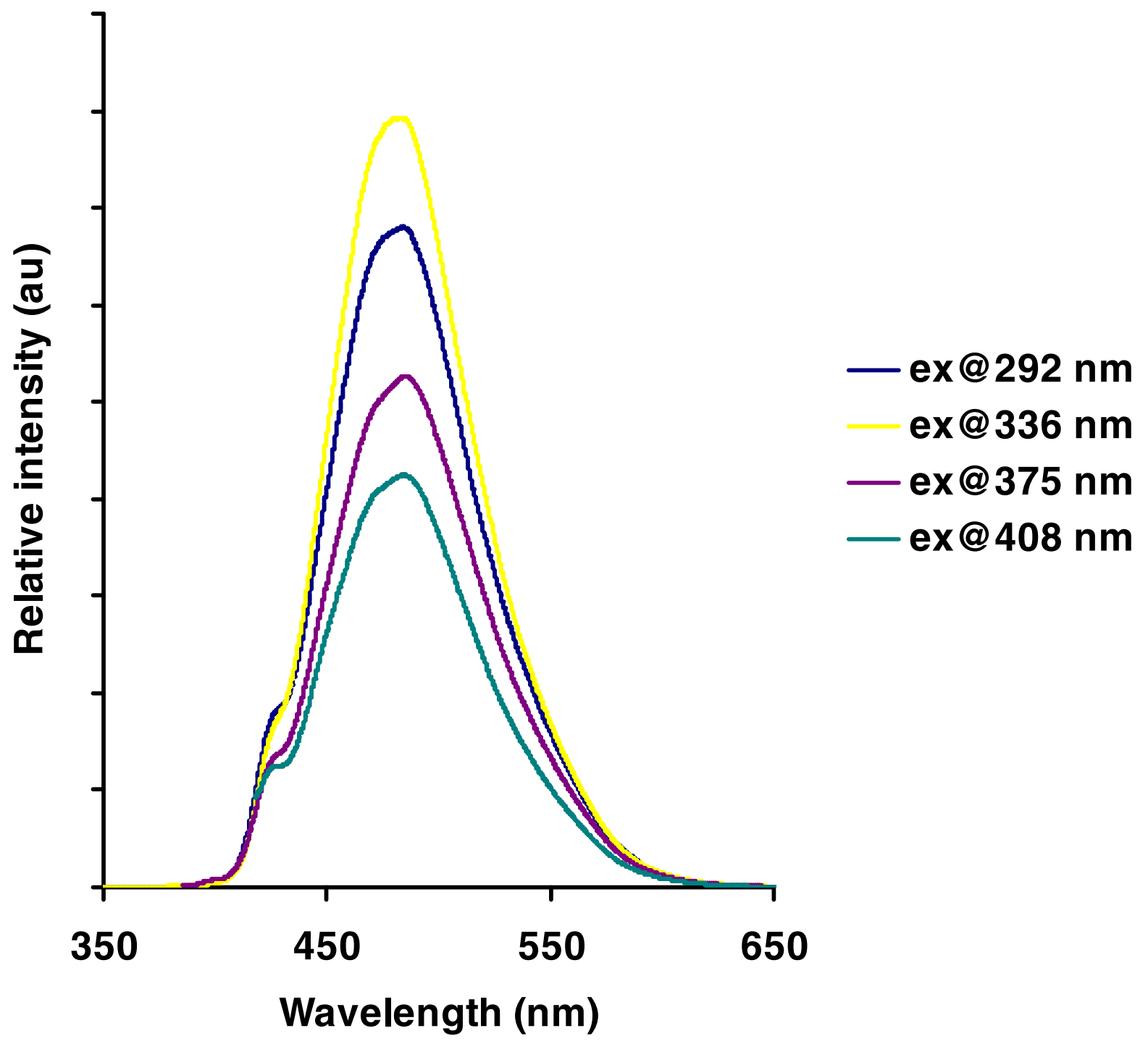

Figure 4. Fluorescence spectra of $\mathbf{1}$ at different excitation wavelengths in cyclohexane (1 x $\left.10^{-5} \mathrm{M}\right)$. 


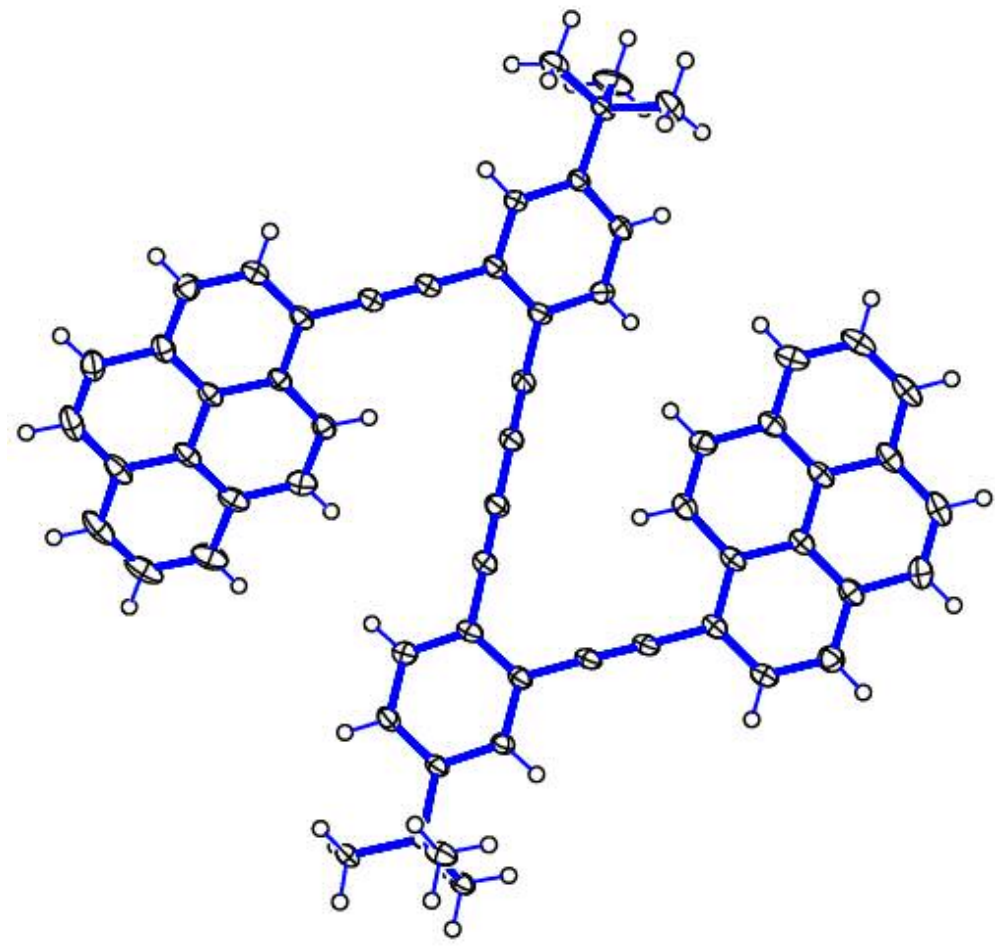

open conformer

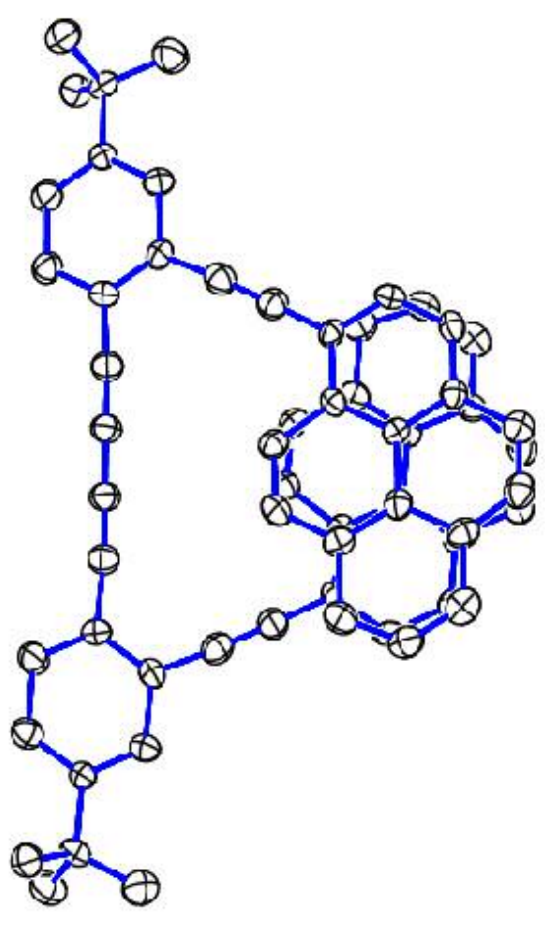

closed conformer

Figure 5. ORTEP diagram of the structure of $\mathbf{1 a}$ (left) and 1b (right) in the crystal. 1a possesses a centre of inversion and $\mathbf{1 b}$ possesses a two fold axis of rotation. 

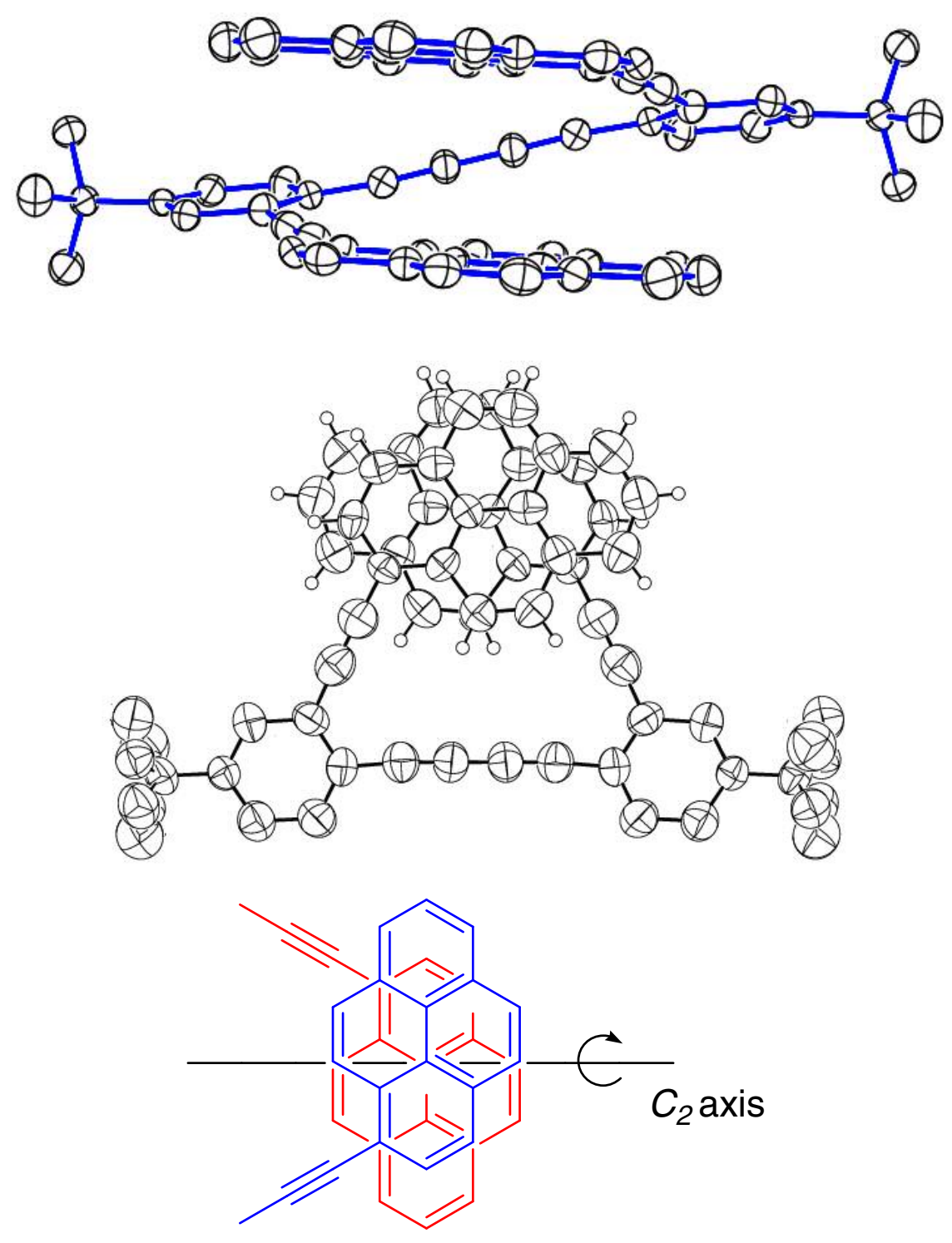

Figure 6. Another view of the structure of $\mathbf{1 b}$ (top) in the crystal showing the nonplanar nature of the molecule and its $Z$-shaped structure. The two fold axis passes through the centre of the diacetylenic bridge and the mid-point of the line connecting the C-10 of the two pyrene rings. The normal mean distance between the two pyrene planes is $3.3508 \AA$. The $C_{2}$ axis is shown schematically (bottom). It also indicates that the hydrogen on C-2 of each of the pyrene rings would lie in the shielding zone of the other, due to the displaced parallel $\pi$-stacking of the two pyrene rings. See Figure 16, H-2 and H-3 are the most shielded protons in the NMR spectrum of $\mathbf{1}$ at $-10{ }^{\circ} \mathrm{C}$. 


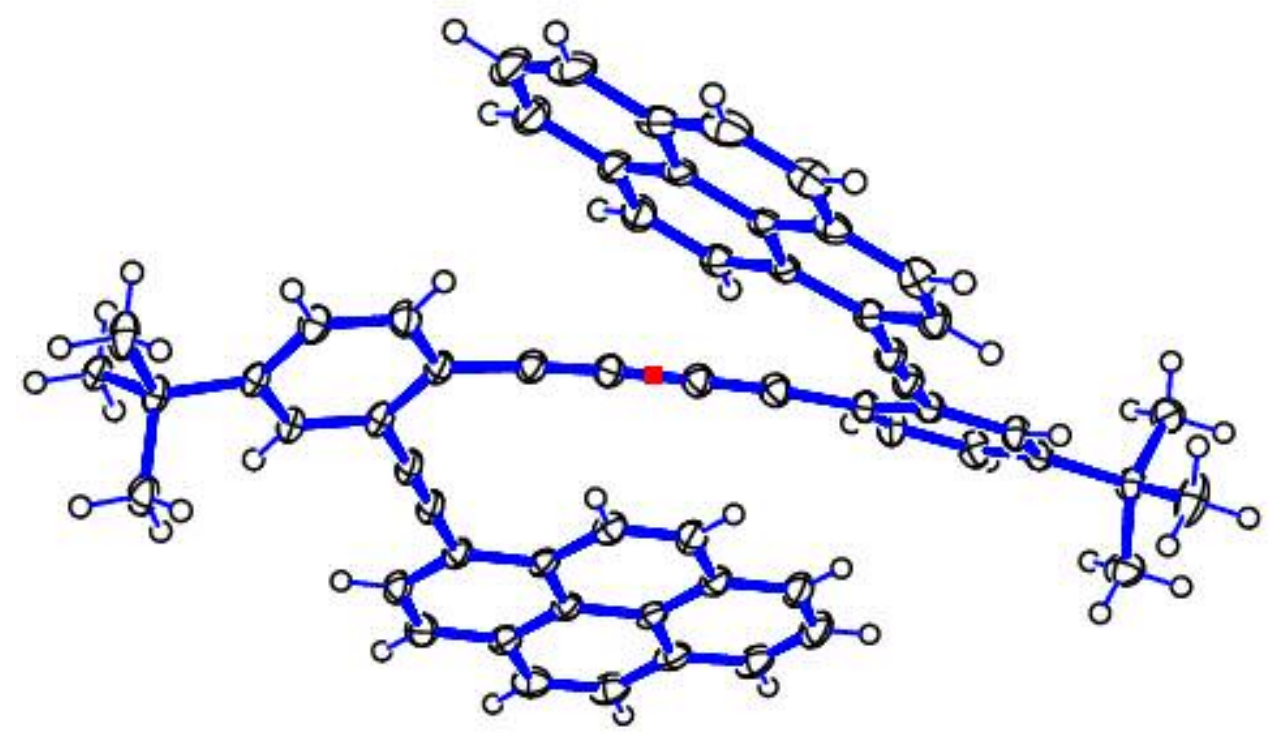

Figure 7. Another view of the structure of $1 \mathbf{a}$ in the crystal showing the non-planar nature of the molecule. The two pyrenes are centrosymmetrically related, the centre of inversion being the mid point of the diacetylenic linkage, indicated by the red dot. 


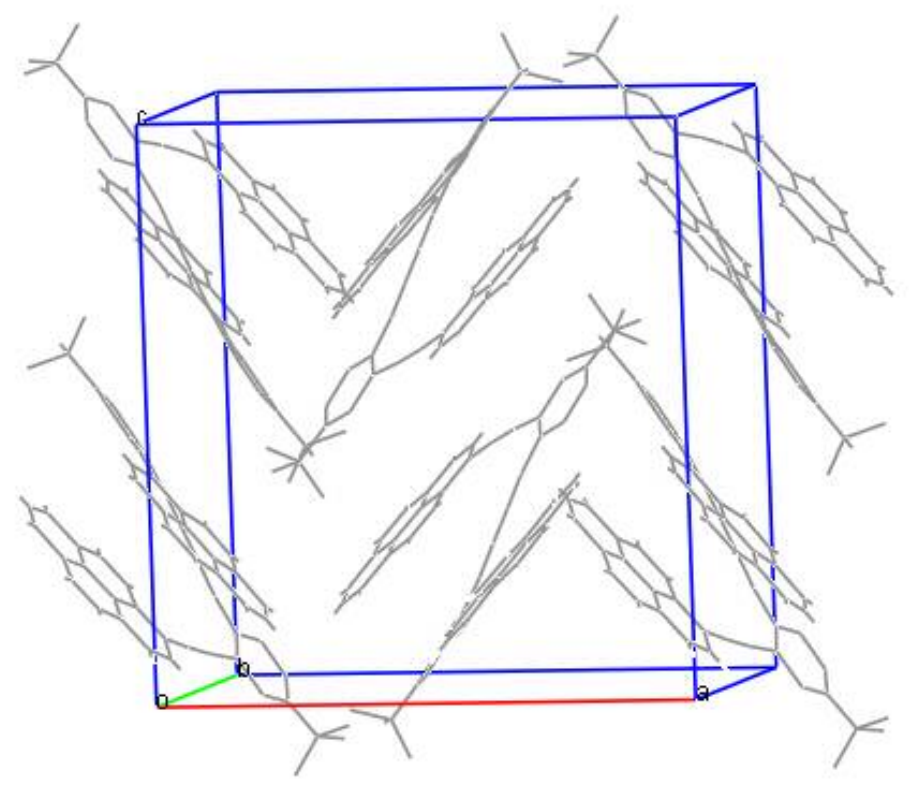

Figure 8. A view of the packing of $\mathbf{1 b}$ along the crystallographic $b$ axis.

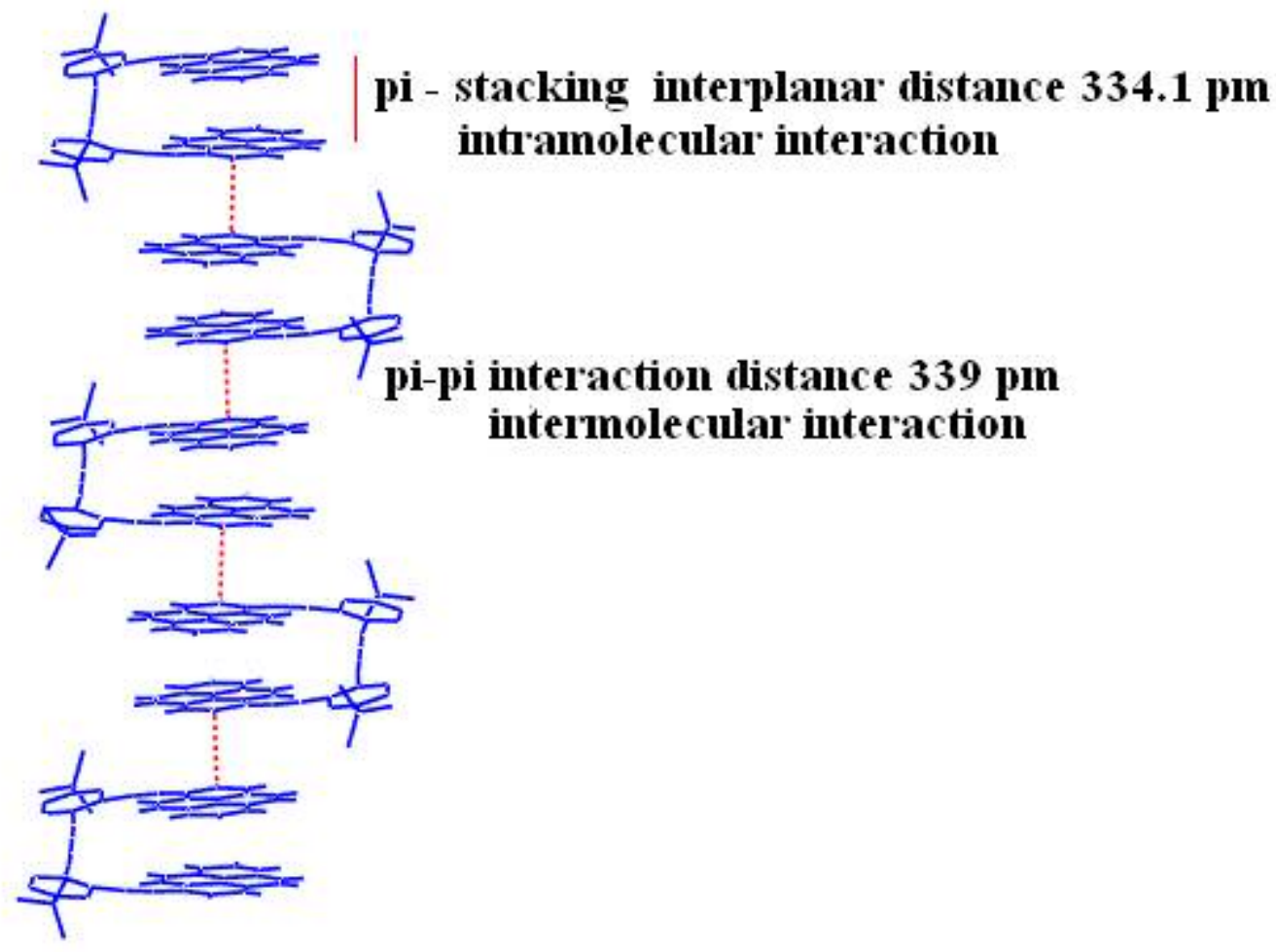

Figure 9. Another view of packing of $\mathbf{1 b}$ in the crystal showing intermolecular $\pi-\pi$ interactions and intramolecular $\pi$-stacking interactions. 


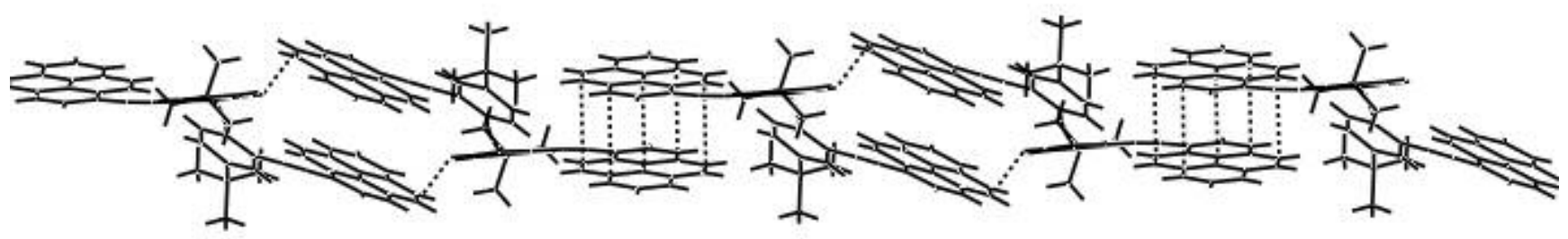

Figure 10. A view of the packing of 1a in the crystal showing intermolecular $\pi$-stacking and $\mathrm{C}-\mathrm{H} . \ldots \pi$ interactions indicated by the dotted lines. The two $\pi$-stacking pyrene rings are ideally parallel with a mean inter-planar distance of $3.341 \AA$. 
Crystallographic data for $1 a$.

Empirical formula $\quad \mathrm{C}_{60} \mathrm{H}_{42}$

Formula weight $\quad 762.94$

Temperature 293(2) K

Wavelength $\quad 0.71073 \AA$

Crystal system, space group Triclinic, P-1

Unit cell dimensions $\quad \mathrm{a}=11.1104(4) \AA \quad$ alpha $=80.639(2) \mathrm{deg}$.

$\mathrm{b}=12.9232(4) \AA \quad$ beta $=70.439(2) \mathrm{deg}$.

$\mathrm{c}=15.1849(5) \AA \quad$ gamma $=85.675(2) \mathrm{deg}$.

Volume

2026.57(12) $\AA^{3}$

Z, Calculated density

$2,1.250 \mathrm{mg} / \mathrm{m}^{3}$

Absorption coefficient

$0.071 \mathrm{~mm}^{-1}$

F (000)

804

Crystal size

$0.3 \times 0.2 \times 0.2 \mathrm{~mm}$

Theta range for data collection

1.44 to $28.33 \mathrm{deg}$.

Limiting indices

$-14 \leq \mathrm{h} \leq 14,-17 \leq \mathrm{k} \leq 17,-20 \leq 1 \leq 20$

Reflections collected / unique

$27283 / 9822[\mathrm{R}($ int $)=0.0302]$

Completeness to theta

$25.00,98.4 \%$

Absorption correction

Semi-empirical from equivalents

Max. and min. transmission

1.0000 and 0.9200

Refinement method

Full-matrix least-squares on $\mathrm{F}^{2}$

Data / restraints / parameters

9822 / 0 / 541

Goodness-of-fit on $\mathrm{F}^{2}$

1.032

Final $\mathrm{R}$ indices $[\mathrm{I}>2 \operatorname{sigma}(\mathrm{I})]$

$\mathrm{R} 1=0.0529, \mathrm{wR} 2=0.1284$

$\mathrm{R}$ indices (all data)

$\mathrm{R} 1=0.0887, \mathrm{wR} 2=0.1501$

Largest diff. peak and hole

0.447 and -0.218 e. $\AA^{-3}$ 
Crystallographic data for $\mathbf{1 b}$.

Empirical formula

Formula weight

Temperature

Wavelength

Crystal system, space group

Unit cell dimensions

Volume

$\mathrm{Z}$, Calculated density

Absorption coefficient

F (000)

Crystal size

Theta range for data collection

Limiting indices

Reflections collected / unique

Completeness to theta

Absorption correction

Max. and min. transmission

Refinement method

Data / restraints / parameters

Goodness-of-fit on $\mathrm{F}^{2}$

Final R indices [I $>2 \operatorname{sigma}(\mathrm{I})]$

$\mathrm{R}$ indices (all data)

Largest diff. peak and hole
$\mathrm{C}_{60} \mathrm{H}_{42}$

762.94

293(2) K

$0.71073 \AA$

Orthorhombic, Pbcn

$\mathrm{a}=18.431(2) \AA \quad$ alpha $=90 \mathrm{deg}$.

$\mathrm{b}=11.8956(14) \AA \quad$ beta $=90 \mathrm{deg}$.

$\mathrm{c}=19.474(2) \AA \quad$ gamma $=90 \mathrm{deg}$.

4269.7(8) $\AA^{3}$

$4,1.187 \mathrm{mg} / \mathrm{m}^{3}$

$0.067 \mathrm{~mm}^{-1}$

1608

$0.3 \times 0.2 \times 0.2 \mathrm{~mm}$

2.09 to $25 \mathrm{deg}$.

$-16 \leq \mathrm{h} \leq 20,-10 \leq \mathrm{k} \leq 13,-17 \leq 1 \leq 22$

$16533 / 3678[\mathrm{R}(\mathrm{int})=0.0689]$

$25,97.9 \%$

Semi-empirical from equivalents

1.0000 and 0.9200

Full-matrix least-squares on $\mathrm{F}^{2}$

3678 / 199 / 301

1.363

$\mathrm{R} 1=0.1174, \mathrm{wR}_{2}=0.4286$

$\mathrm{R} 1=0.1317, \mathrm{wR} 2=0.4362$

0.638 and -0.251 e. $\AA^{-3}$ 


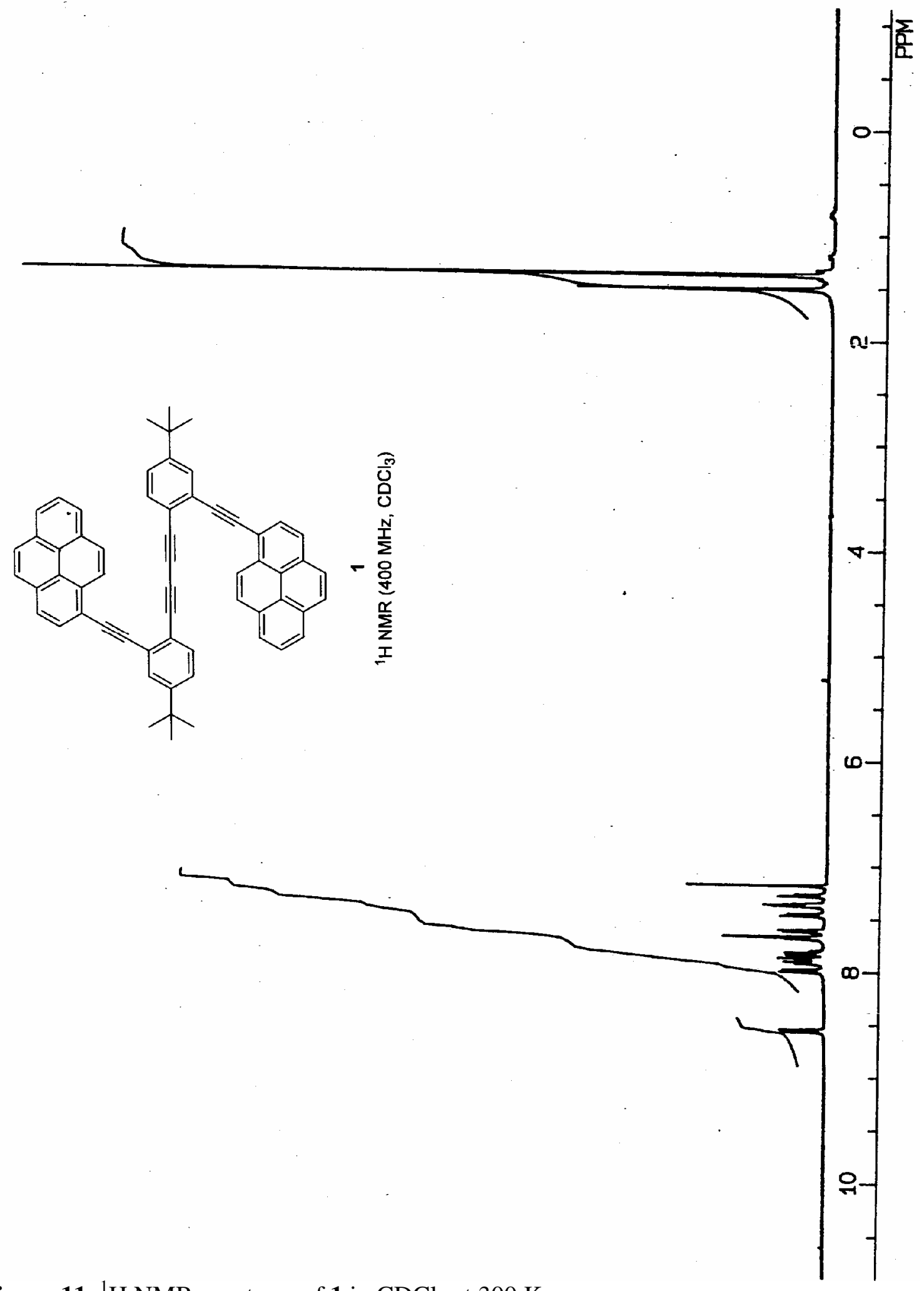

Figure 11. ${ }^{1} \mathrm{H} \mathrm{NMR}$ spectrum of 1 in $\mathrm{CDCl}_{3}$ at $300 \mathrm{~K}$. 


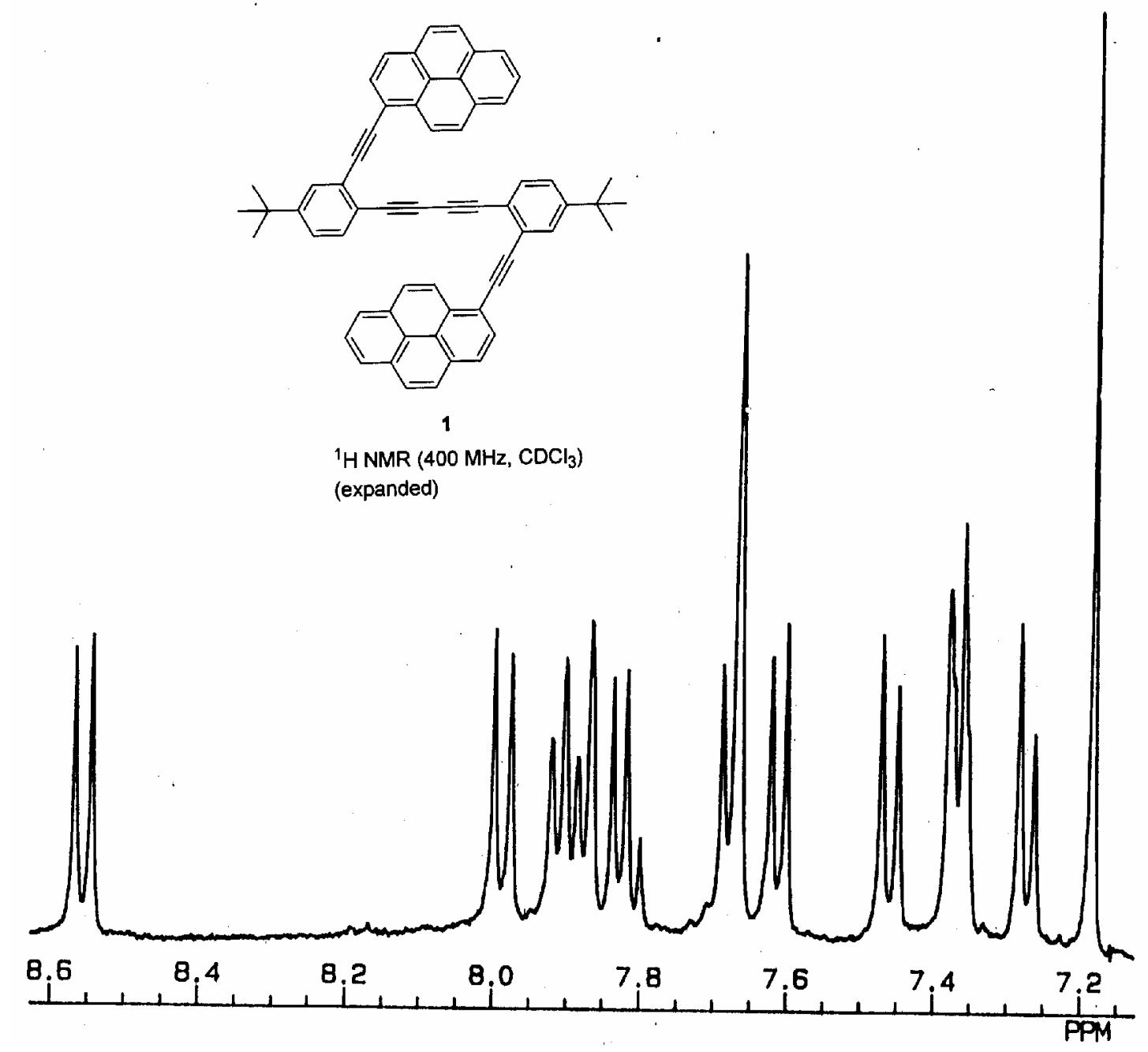

Figure 12. Expanded aromatic region of the ${ }^{1} \mathrm{H}$ NMR spectrum of $\mathbf{1}$ in $\mathrm{CDCl}_{3}$ at $300 \mathrm{~K}$. 


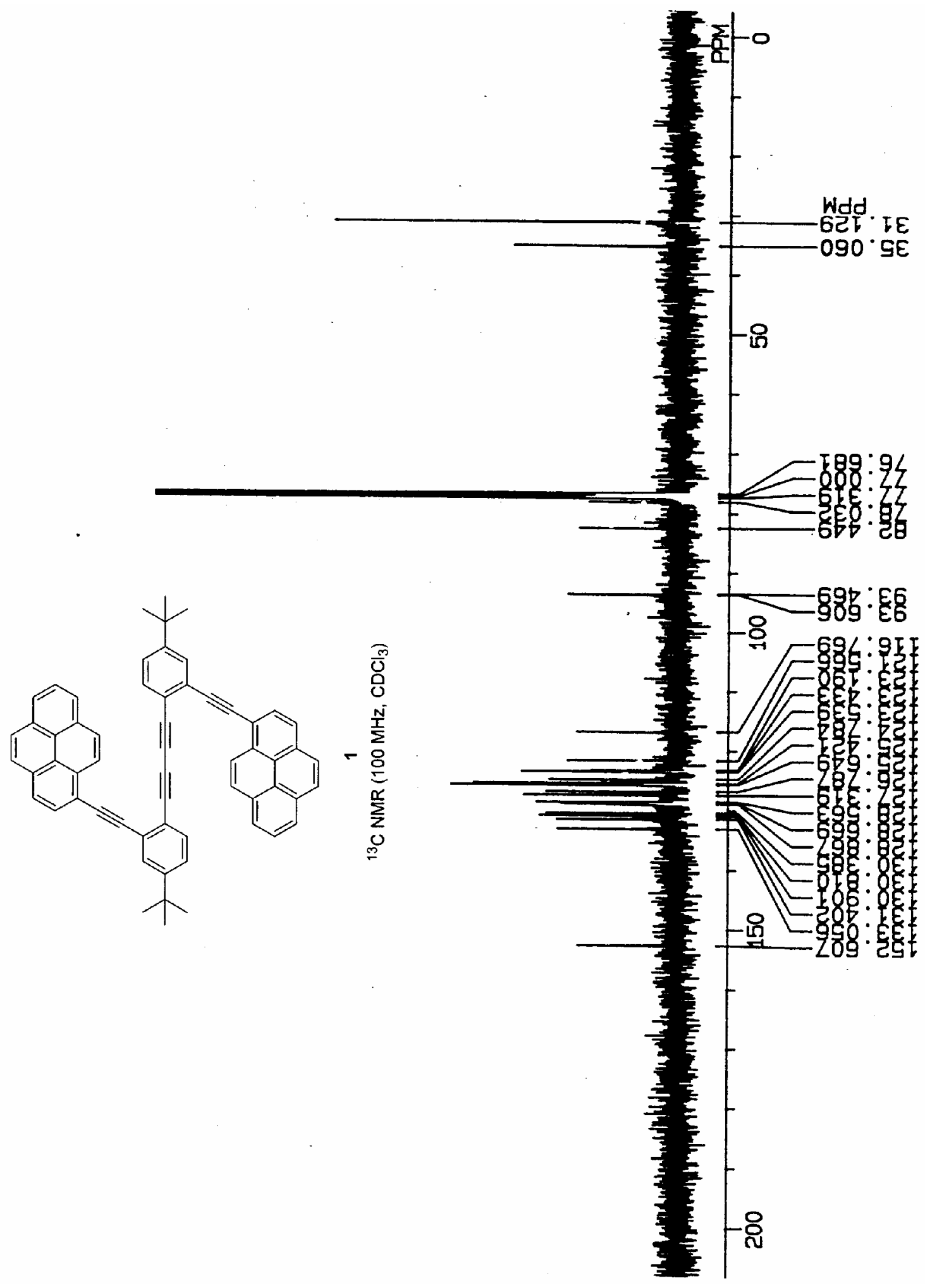

Figure 13. $100 \mathrm{MHz}{ }^{13} \mathrm{C} \mathrm{NMR}$ spectrum of $\mathbf{1}$ in $\mathrm{CDCl}_{3}$. 


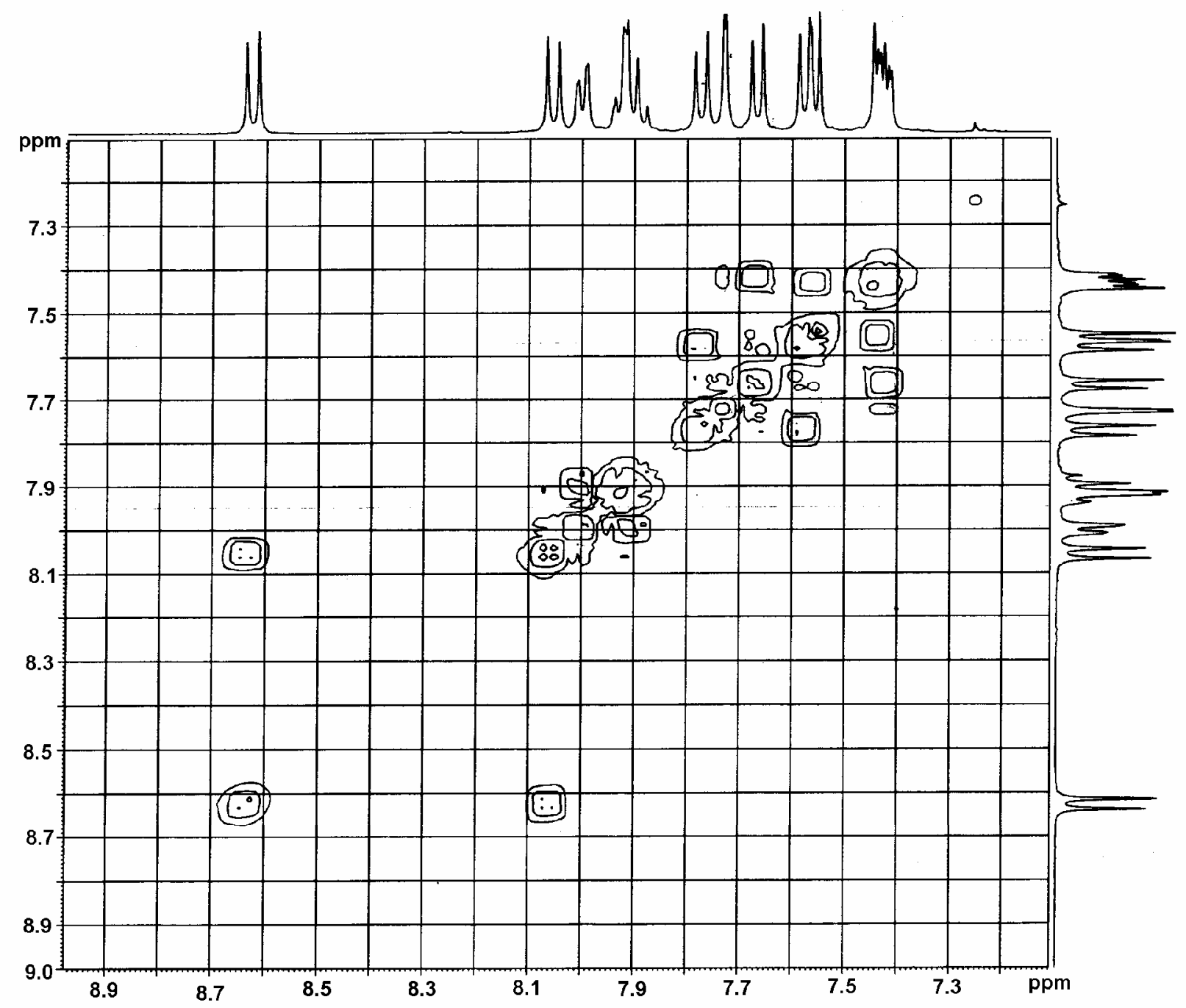

Figure 14. ${ }^{1} \mathrm{H}-{ }^{1} \mathrm{H}$ COSY spectrum of $\mathbf{1}$ in $\mathrm{CDCl}_{2} \mathrm{CDCl}_{2}$ at $300 \mathrm{~K}$. 

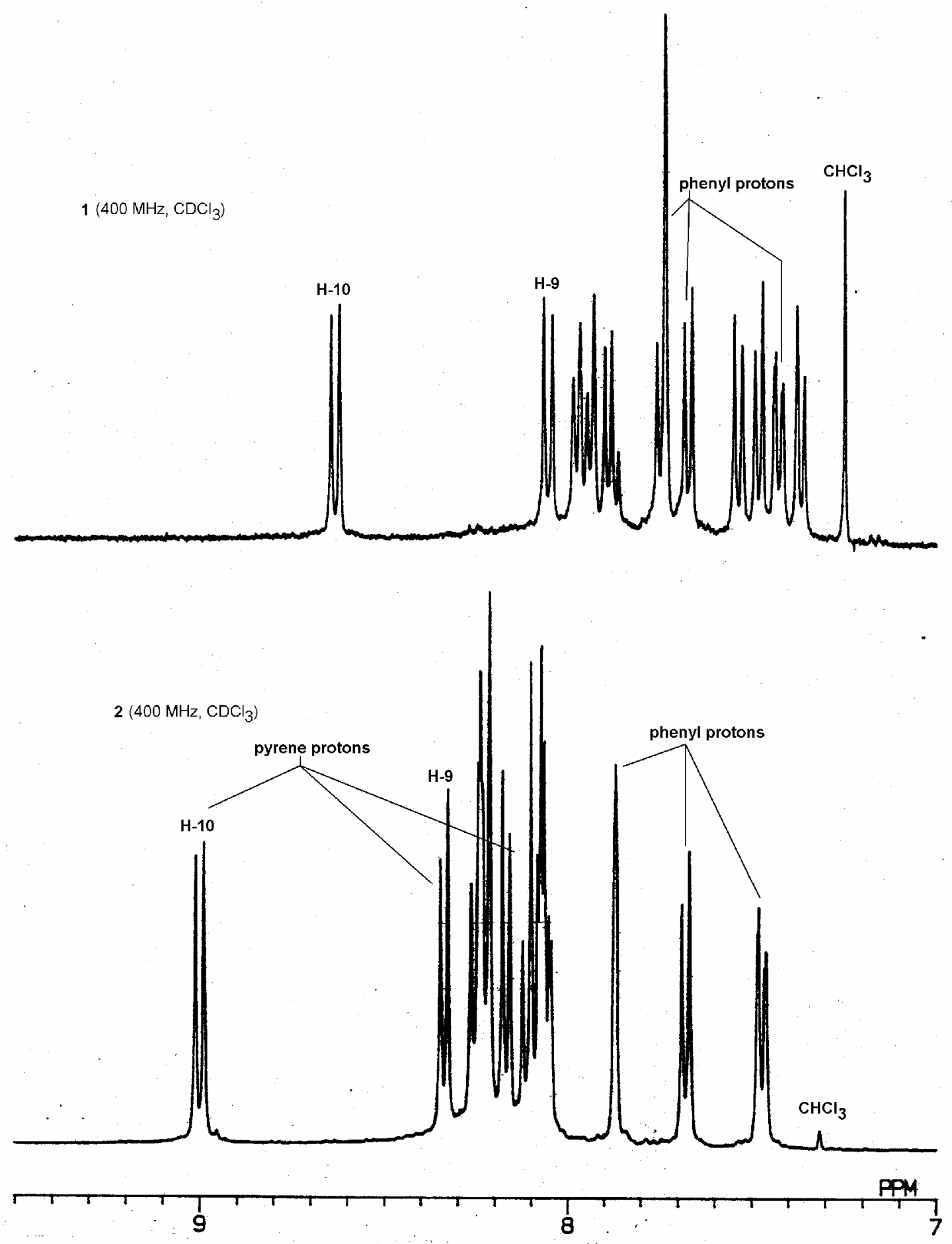

Figure 15. Comparison of ${ }^{1} \mathrm{H}$ NMR spectra of $\mathbf{1}$ and $\mathbf{2}$ in $\mathrm{CDCl}_{3}$. Due to $\pi$-stacking interactions the pyrene protons in $\mathbf{1}$ are more shielded than the pyrene protons of $\mathbf{2}$. The pyrene protons are also more resolved in $\mathbf{1}$ than in $\mathbf{2}$ for the same reason. 

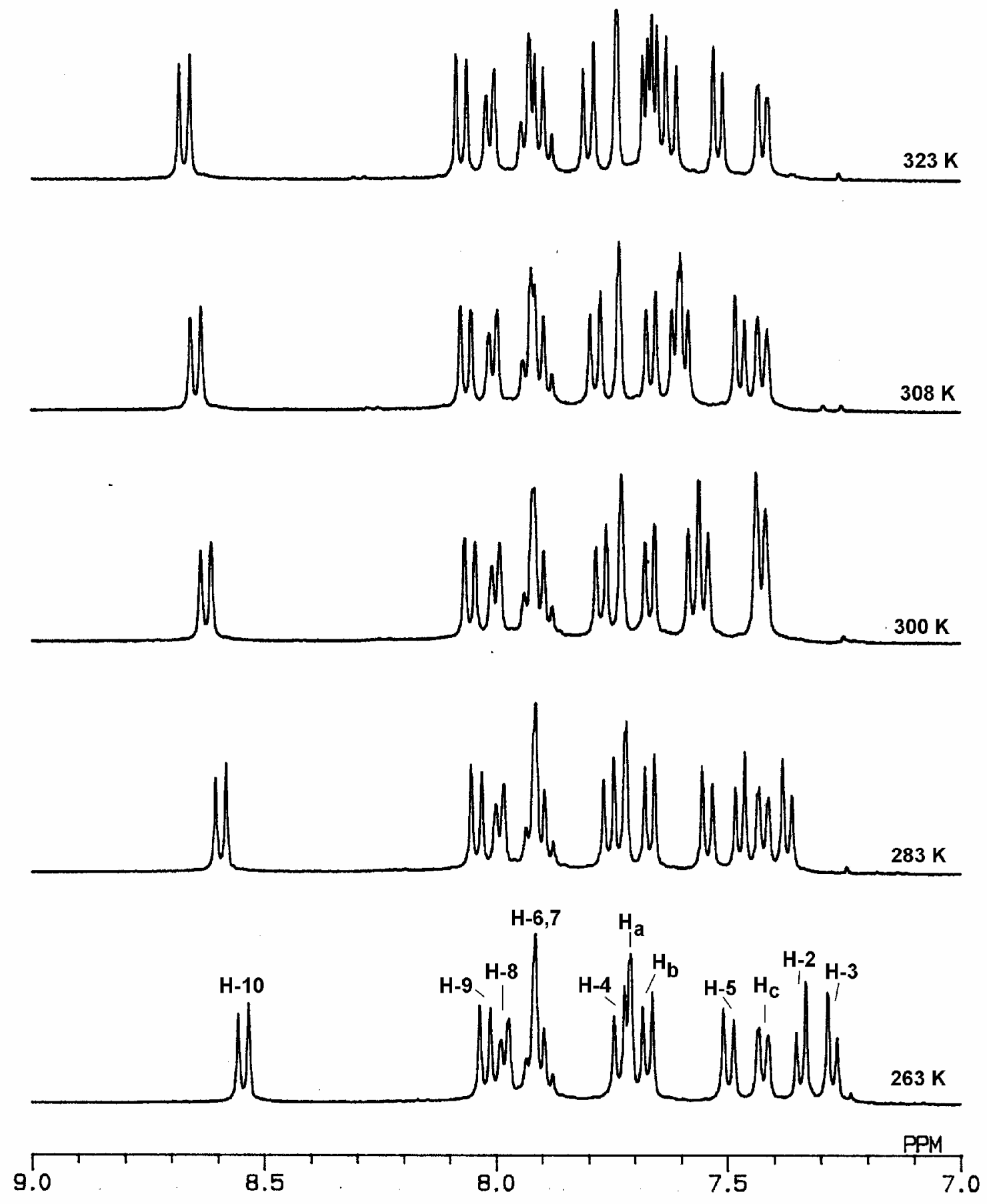

Figure 16. ${ }^{1} \mathrm{H}$ NMR spectra ( $400 \mathrm{MHz}$ ) of $\mathbf{1}$ at different temperatures in the range of 263 to $323 \mathrm{~K}$ in $\mathrm{CDCl}_{2} \mathrm{CDCl}_{2}$. The assignments are based on the ${ }^{1} \mathrm{H}-{ }^{1} \mathrm{H}$ COSY spectrum. Ha, $\mathrm{Hb}$ and $\mathrm{Hc}$ correspond to the protons on the phenyl rings. $\mathrm{H}-2$ to $\mathrm{H}-10$ are the pyrene protons. 

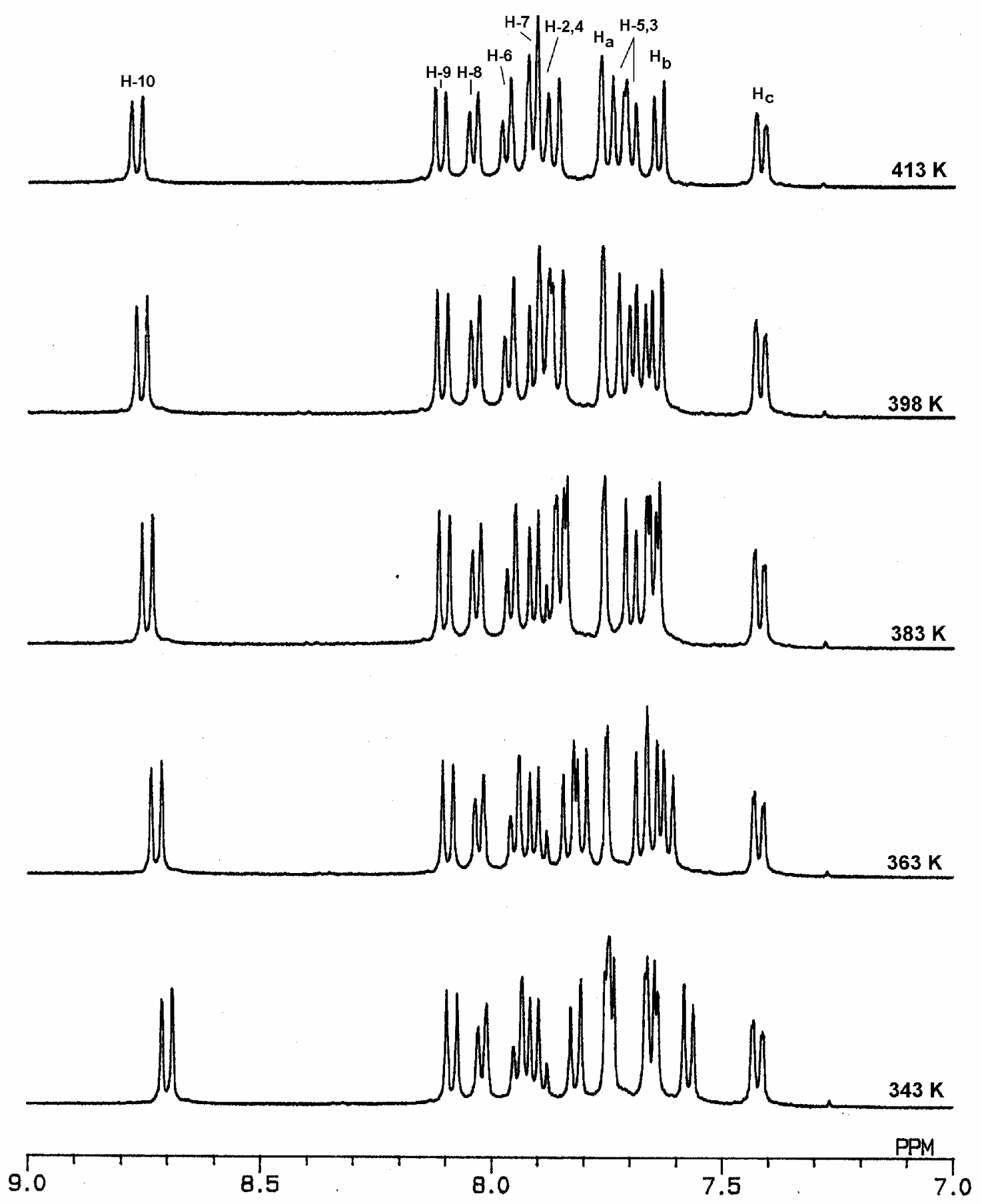

Figure 17. ${ }^{1} \mathrm{H}$ NMR spectra (400 MHz) of $\mathbf{1}$ at different temperatures in the range of 343 to $413 \mathrm{~K}$ in $\mathrm{CDCl}_{2} \mathrm{CDCl}_{2}$ (continuation of Figure 15). 


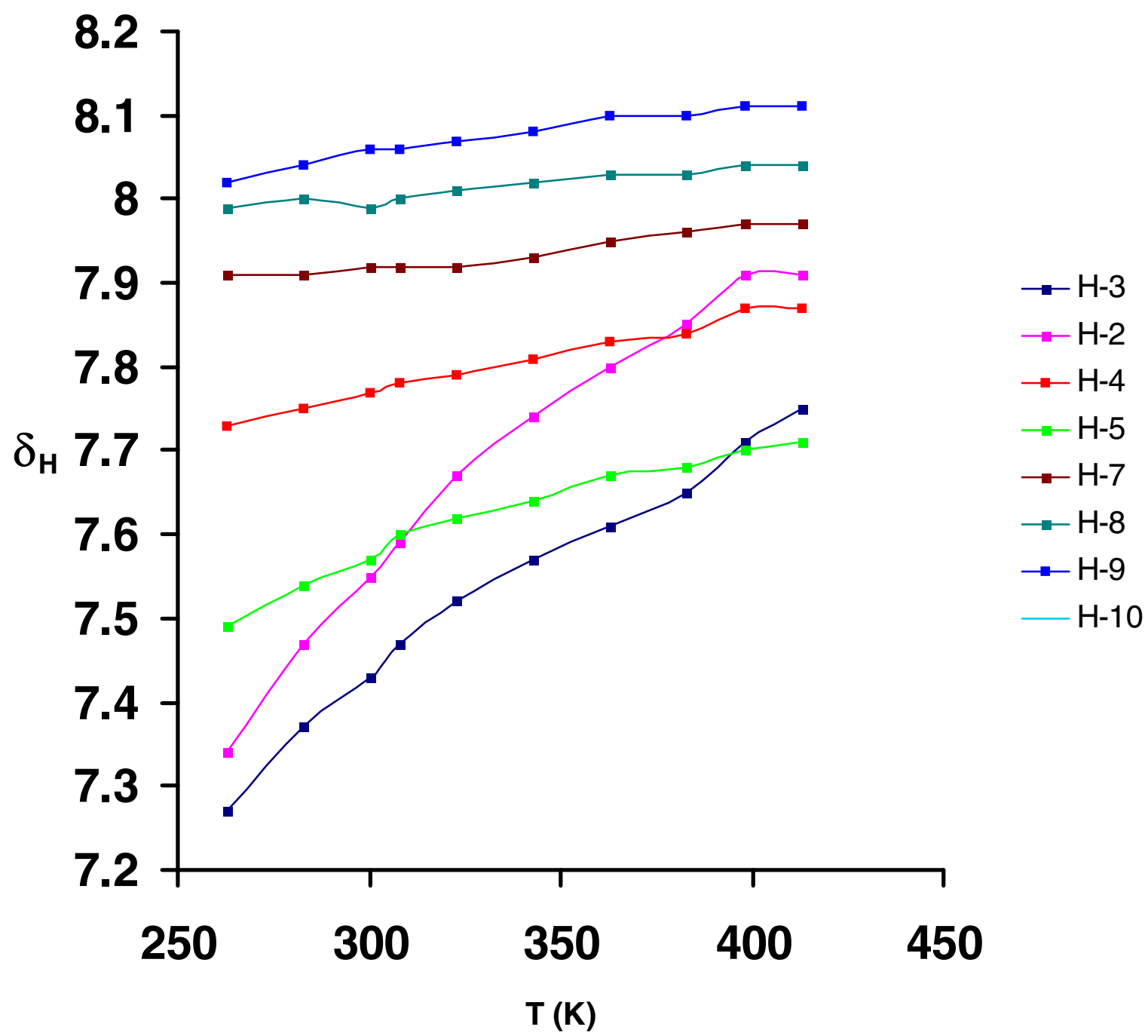

Figure 18. Temperature dependence of proton chemical shifts in $\mathbf{1}$. Data obtained from Figure 16-17. There is a steady increase of the chemical shift of H-4 to H-10 with increasing temperature. The effect is more dramatic in case of $\mathrm{H}-2$ and $\mathrm{H}-3$. 


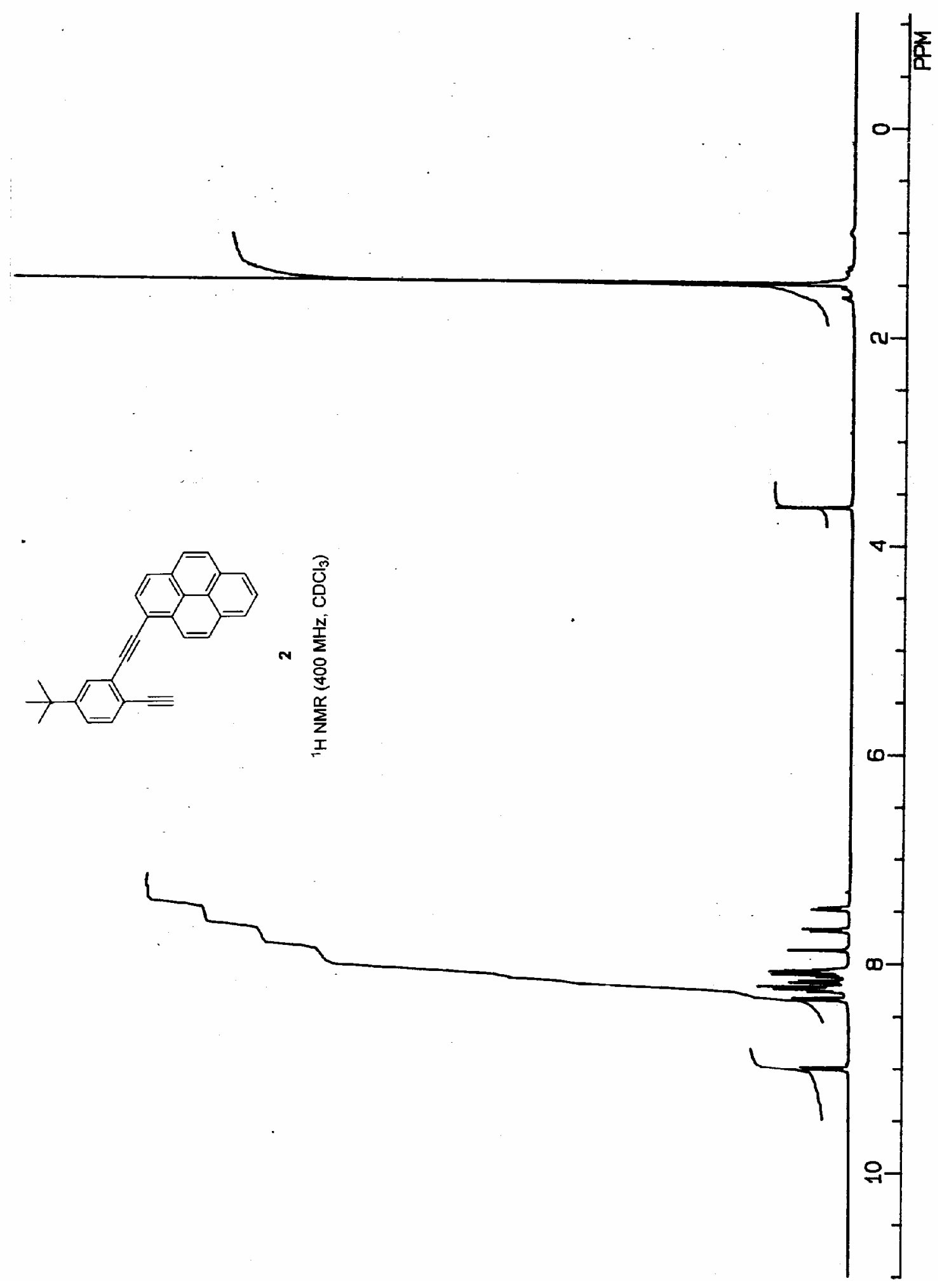

Figure 19. $400 \mathrm{MHz}{ }^{1} \mathrm{H} \mathrm{NMR}$ spectrum of 2 in $\mathrm{CDCl}_{3}$. 


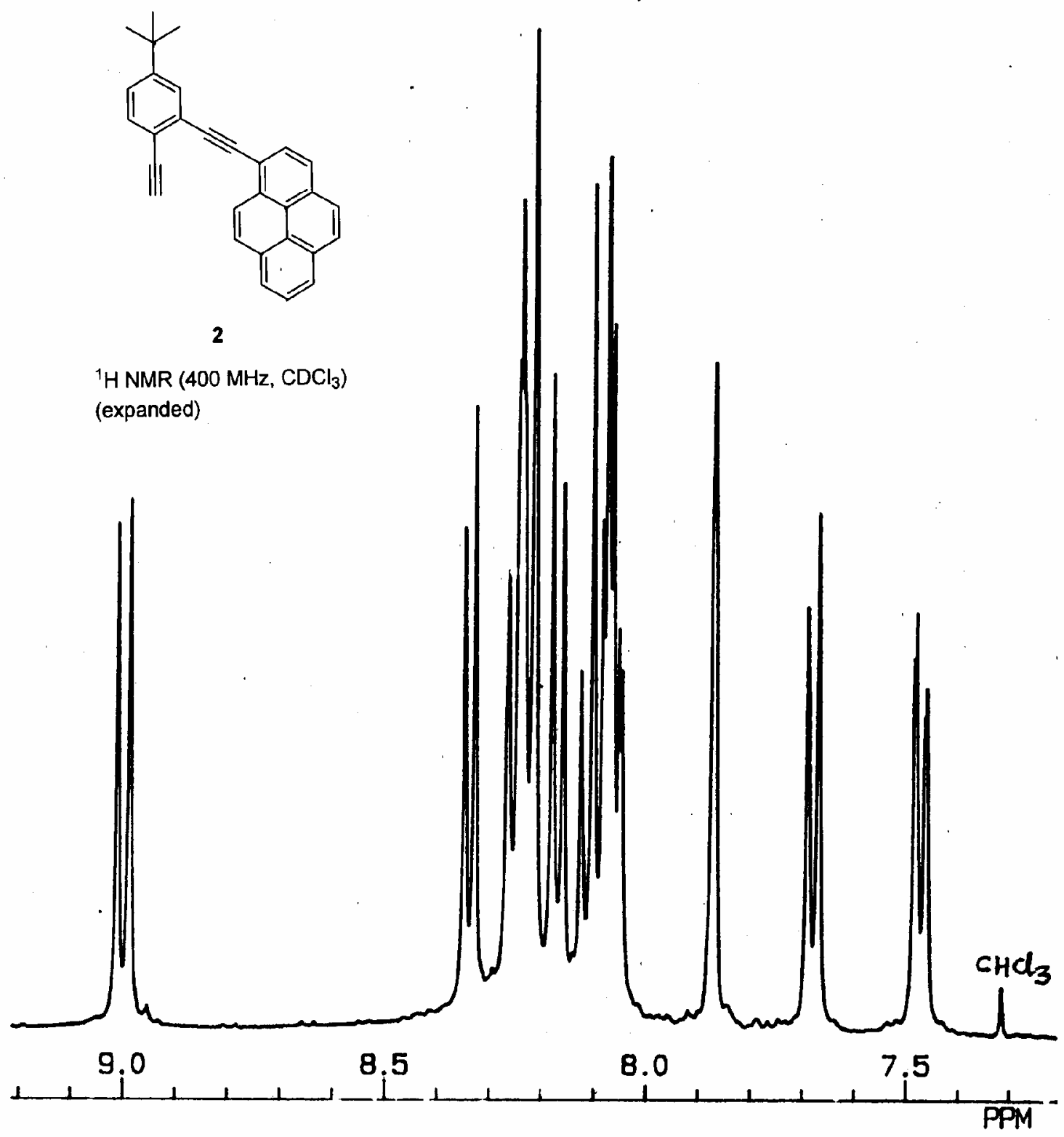

Figure 20. Expanded aromatic region of $400 \mathrm{MHz}{ }^{1} \mathrm{H}$ NMR spectrum of 2 in $\mathrm{CDCl}_{3}$. 


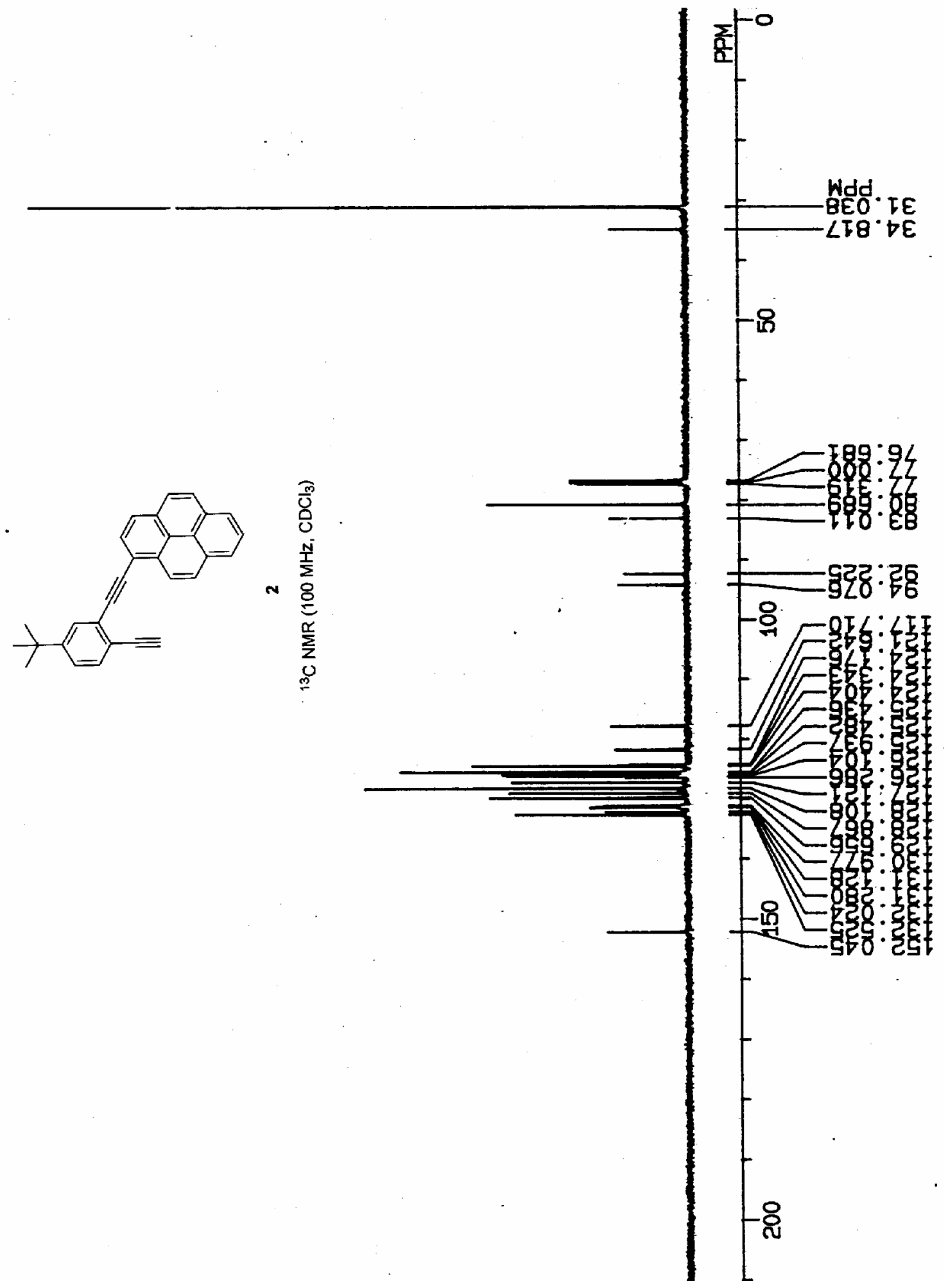

Figure 21. $100 \mathrm{MHz}{ }^{13} \mathrm{C} \mathrm{NMR}$ spectrum of 2 in $\mathrm{CDCl}_{3}$. 


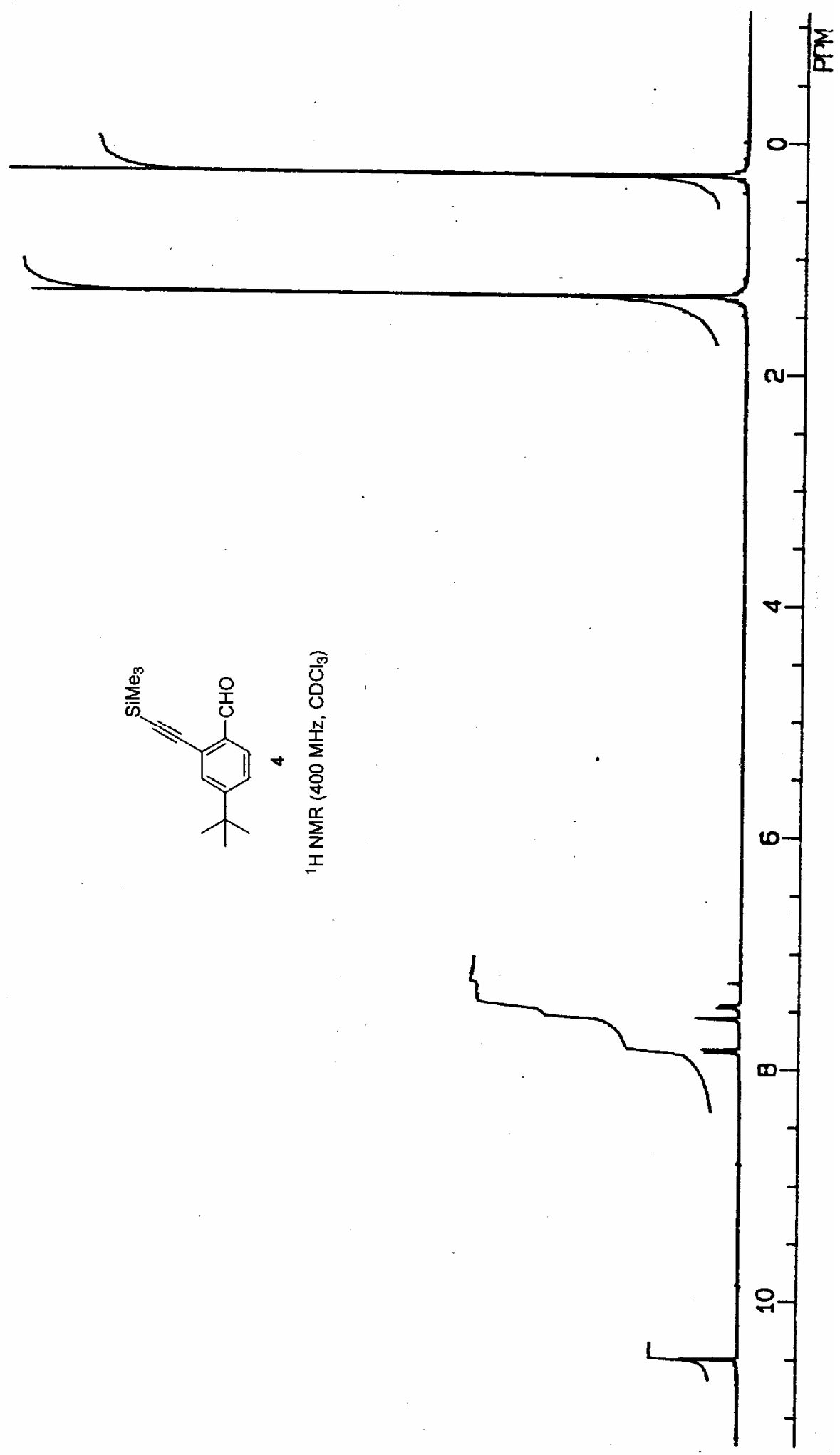

Figure 22. $400 \mathrm{MHz}{ }^{1} \mathrm{H} \mathrm{NMR}$ spectrum of 4 in $\mathrm{CDCl}_{3}$. 

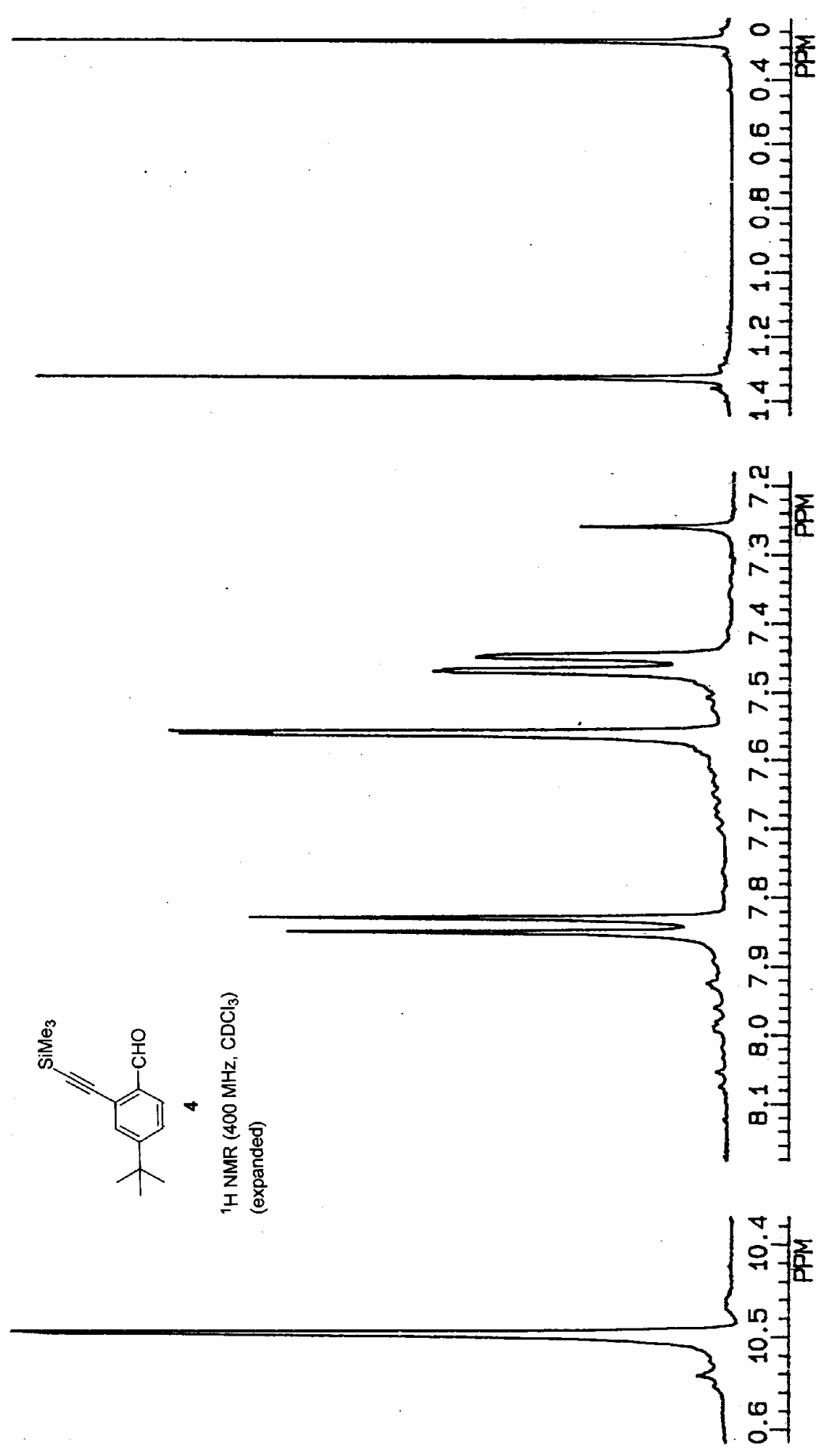

Figure 23. Expanded $400 \mathrm{MHz}{ }^{1} \mathrm{H}$ NMR spectrum of $\mathbf{4}$ in $\mathrm{CDCl}_{3}$. 


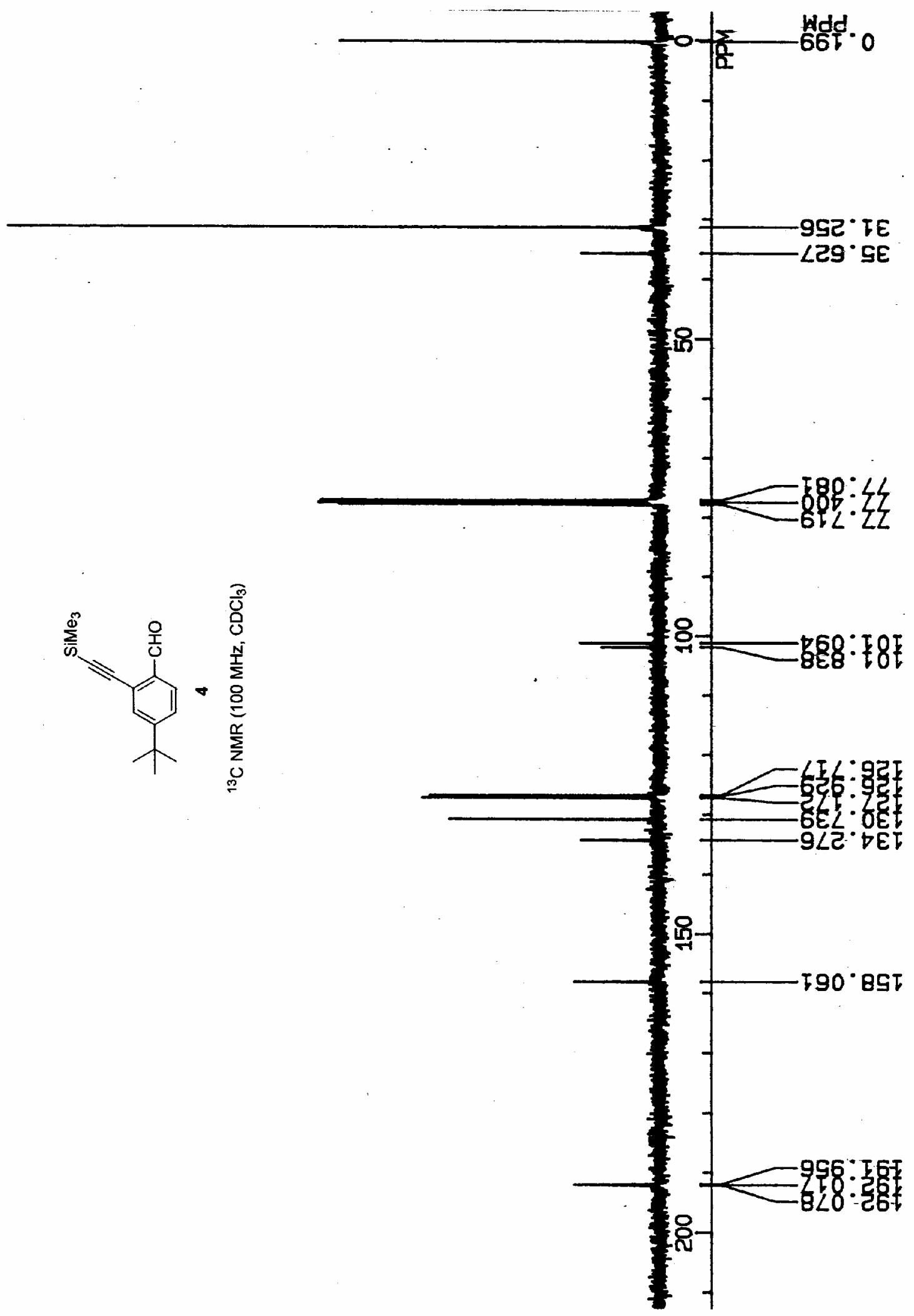

Figure 24. $100 \mathrm{MHz}{ }^{13} \mathrm{C} \mathrm{NMR}$ spectrum of $\mathbf{4}$ in $\mathrm{CDCl}_{3}$. 


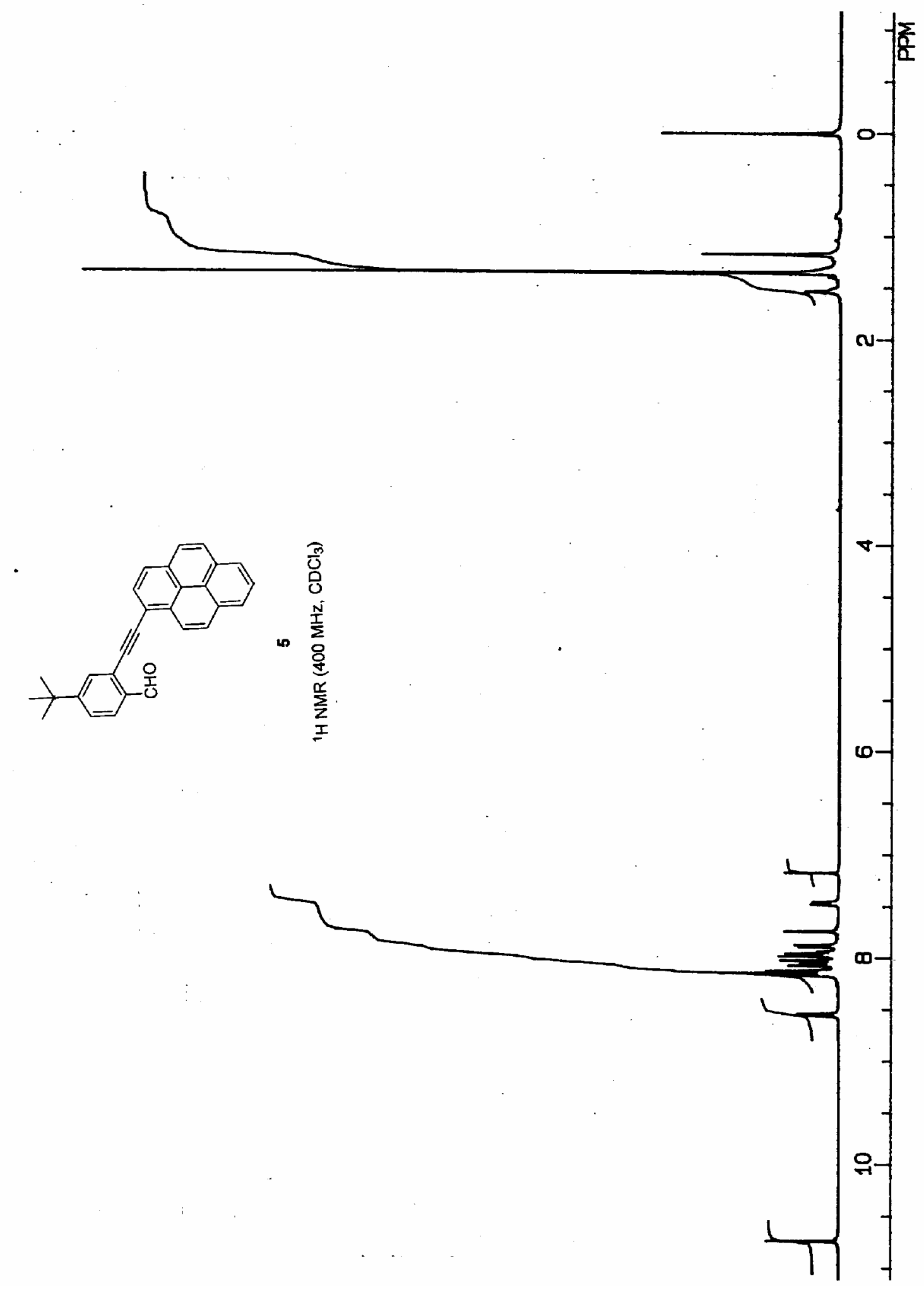

Figure 25. $400 \mathrm{MHz}{ }^{1} \mathrm{H} \mathrm{NMR}$ spectrum of 5 in $\mathrm{CDCl}_{3}$. 

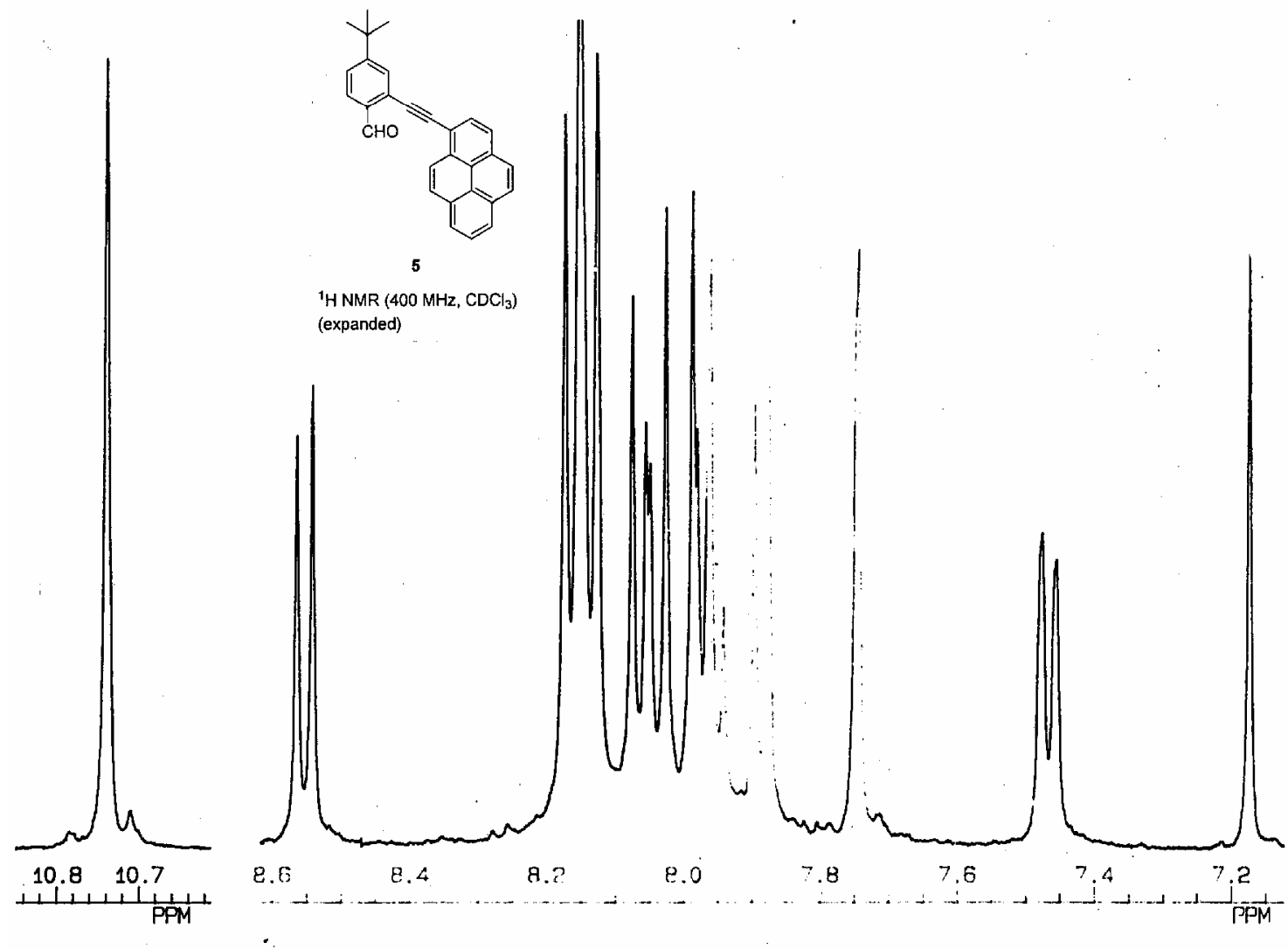

Figure 26. Expanded aromatic region of $400 \mathrm{MHz}{ }^{1} \mathrm{H}$ NMR spectrum of 5 in $\mathrm{CDCl}_{3}$. 


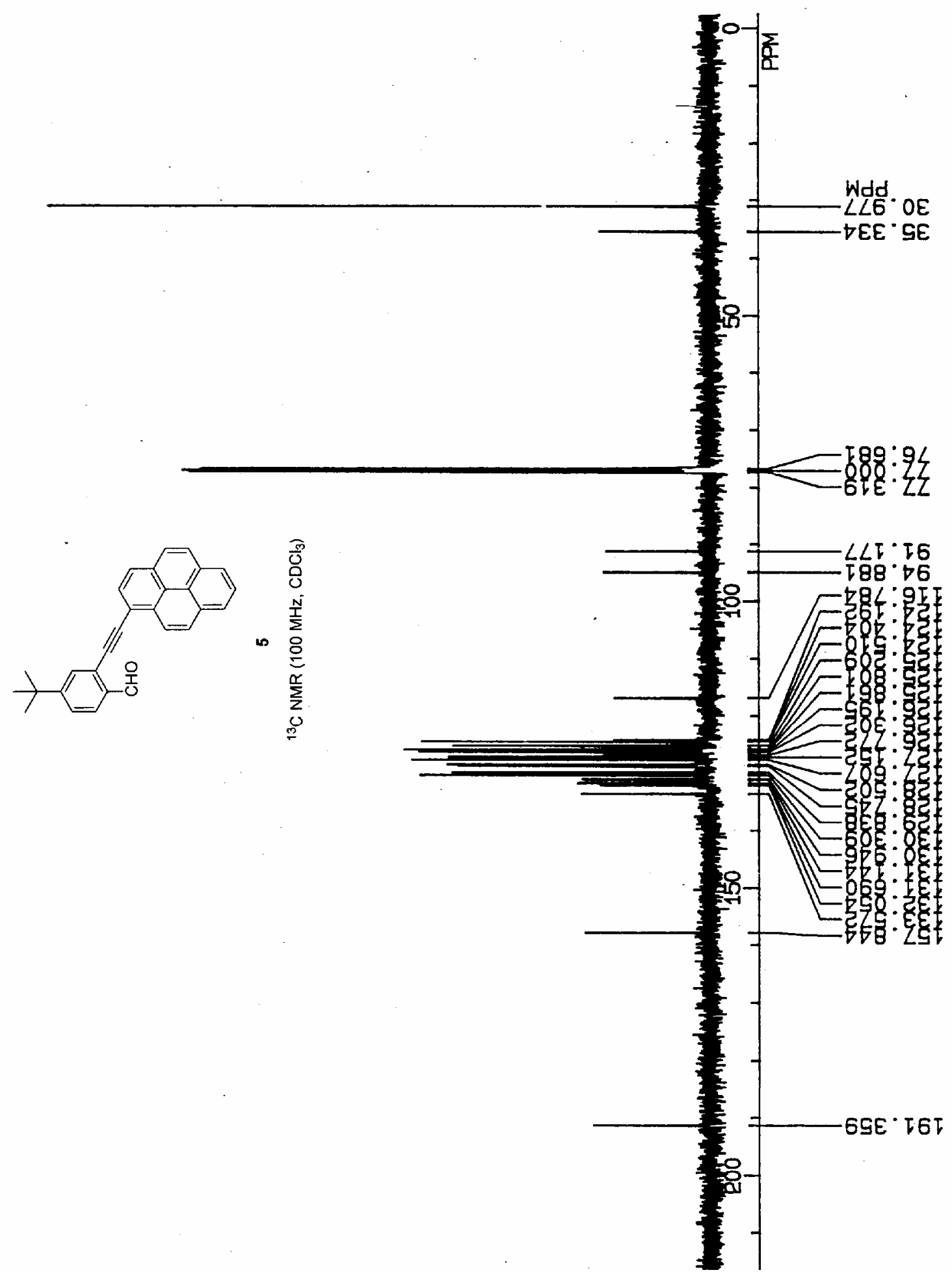

Figure 27. $100 \mathrm{MHz}{ }^{13} \mathrm{C} \mathrm{NMR}$ spectrum of 5 in $\mathrm{CDCl}_{3}$. 


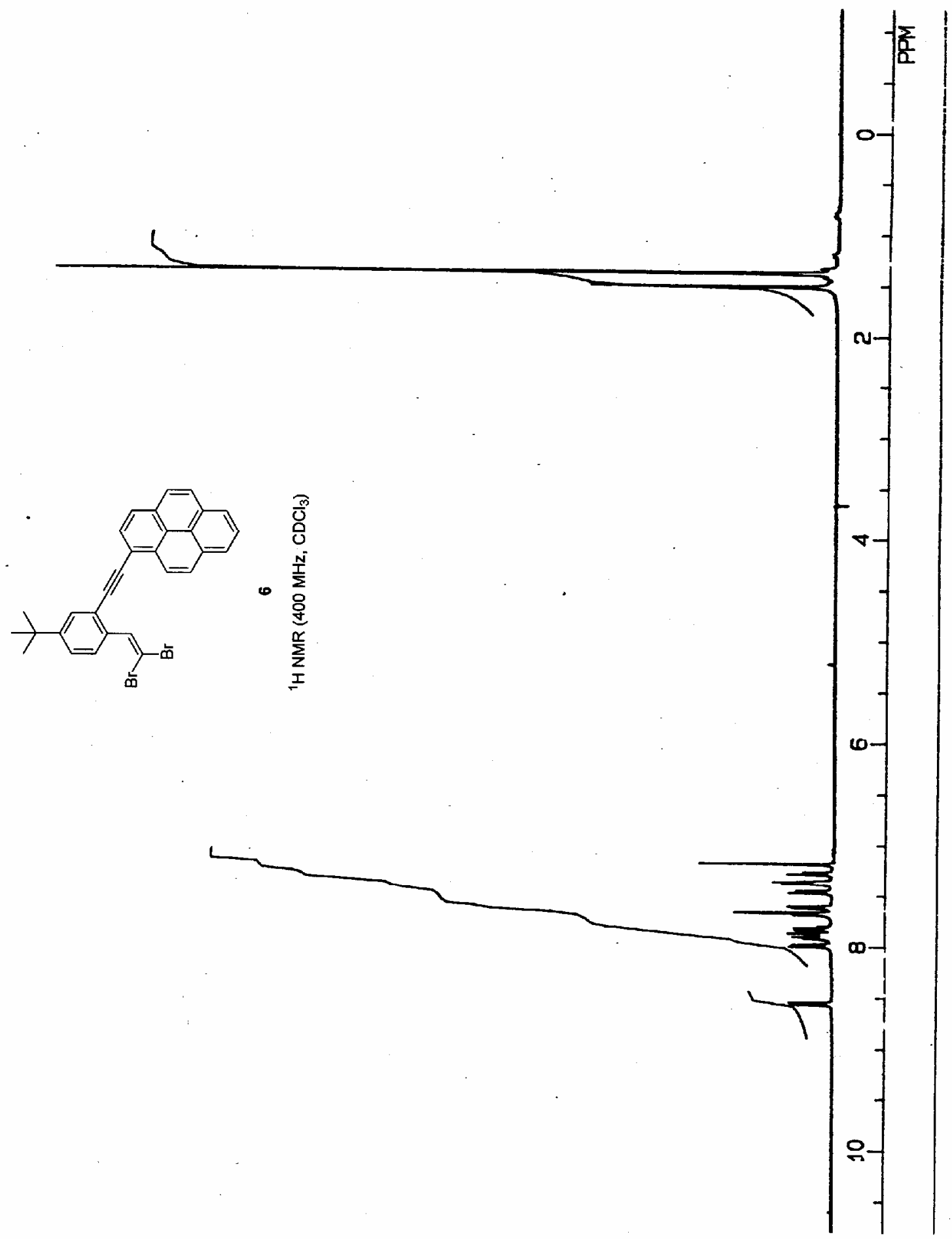

Figure 28. $400 \mathrm{MHz}{ }^{1} \mathrm{H} \mathrm{NMR}$ spectrum of 6 in $\mathrm{CDCl}_{3}$. 


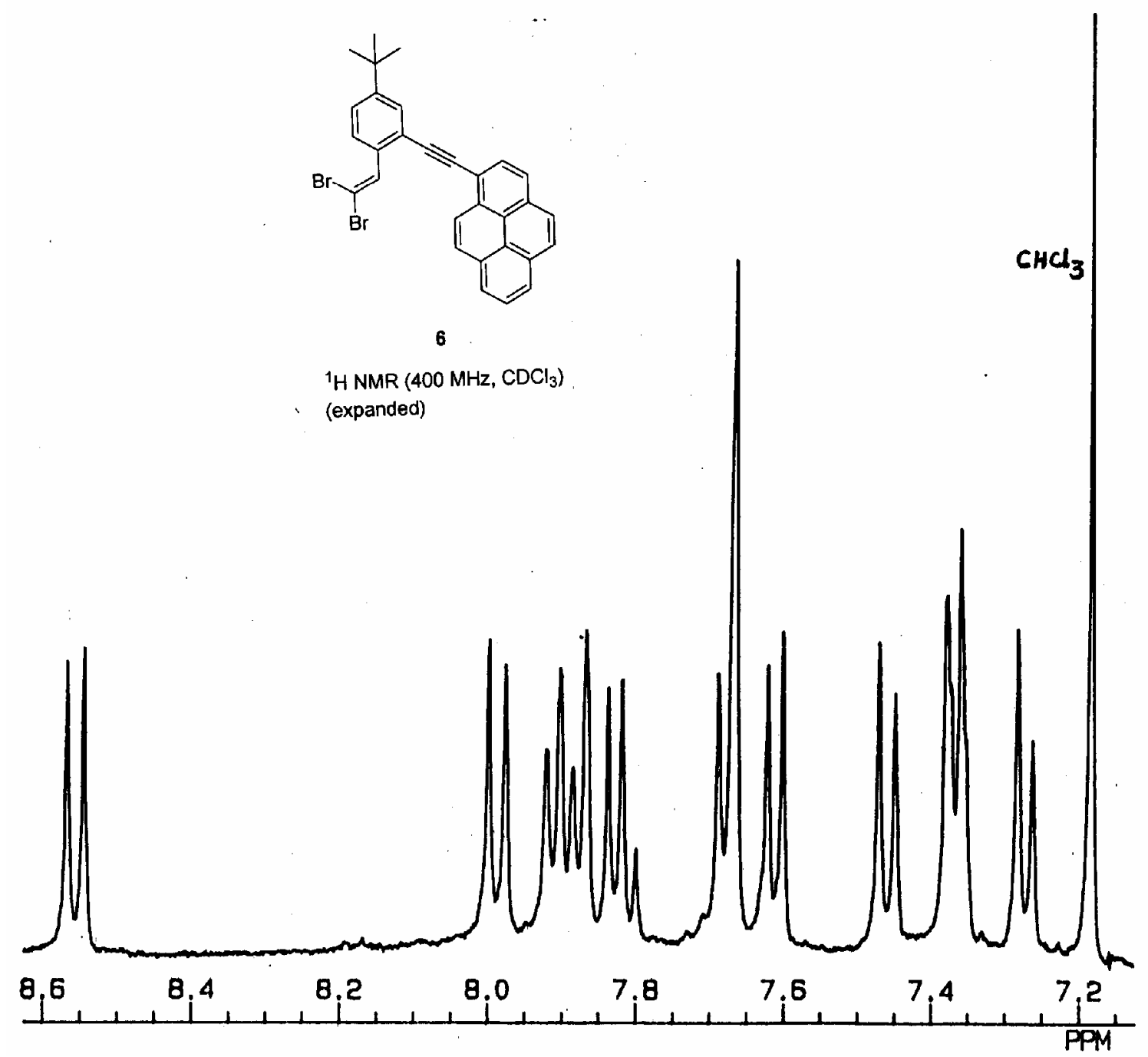

Figure 29. Expanded aromatic region of $400 \mathrm{MHz}{ }^{1} \mathrm{H}$ NMR spectrum of 6 in $\mathrm{CDCl}_{3}$. 


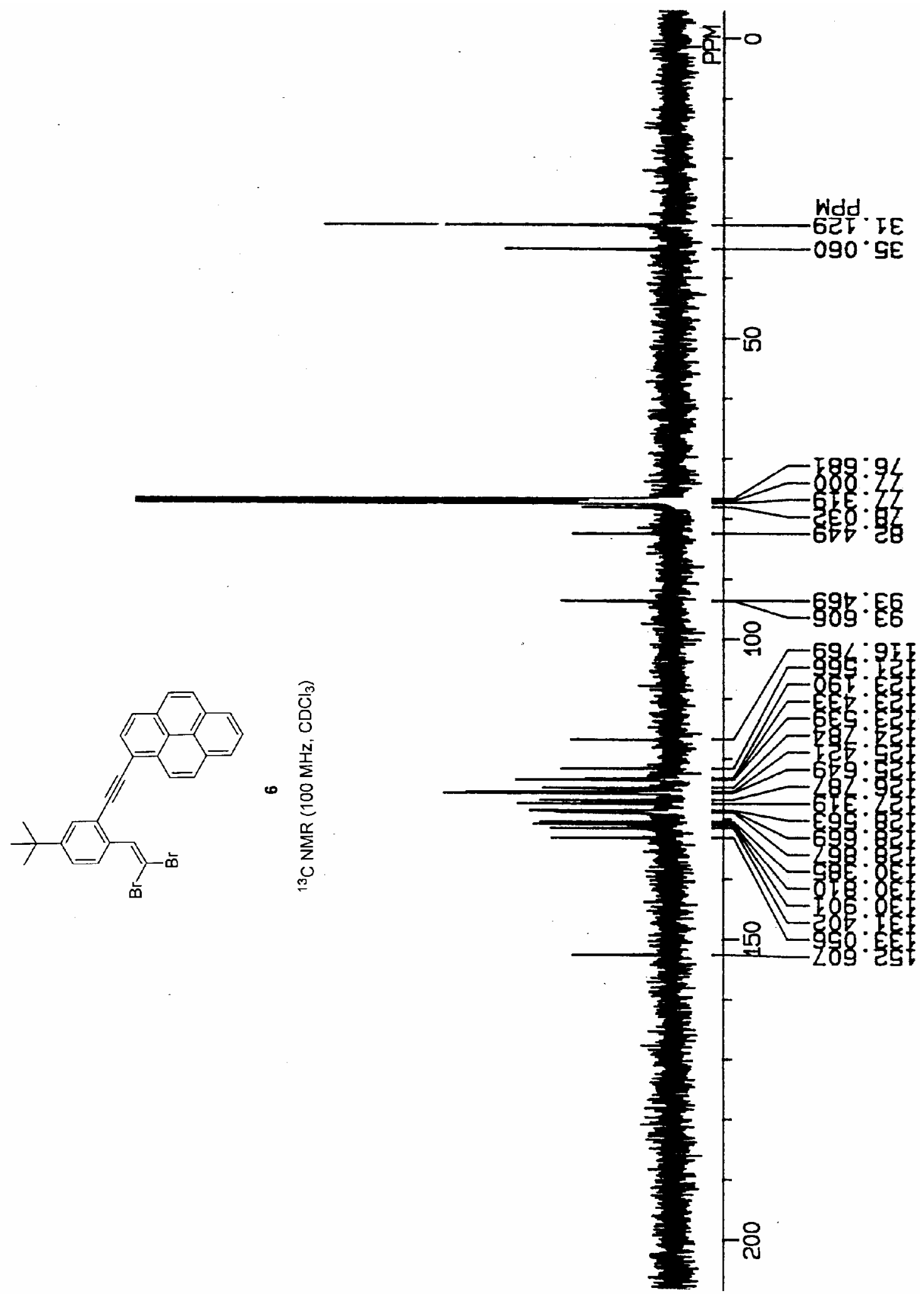

Figure 30. $100 \mathrm{MHz}{ }^{13} \mathrm{C} \mathrm{NMR}$ spectrum of 6 in $\mathrm{CDCl}_{3}$. 


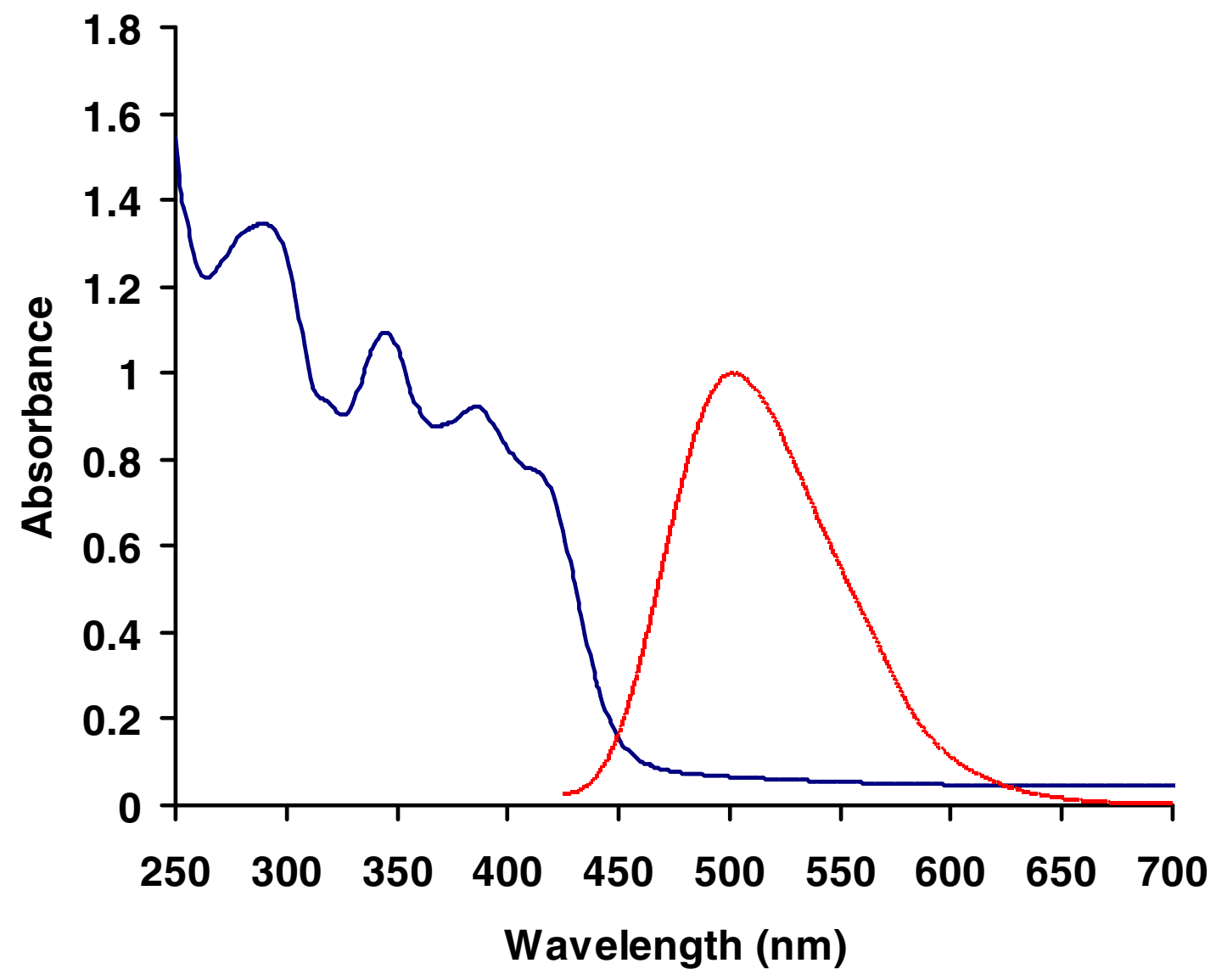

Figure 31. Absorption spectrum (blue) and fluorescence emission (red, $\lambda_{\mathrm{ex}}=385 \mathrm{~nm}$ ) (solid state, thin film on a quartz plate) of $\mathbf{1}$. The emission intensity is normalized and the emission maximum is independent of the excitation wavelength. 


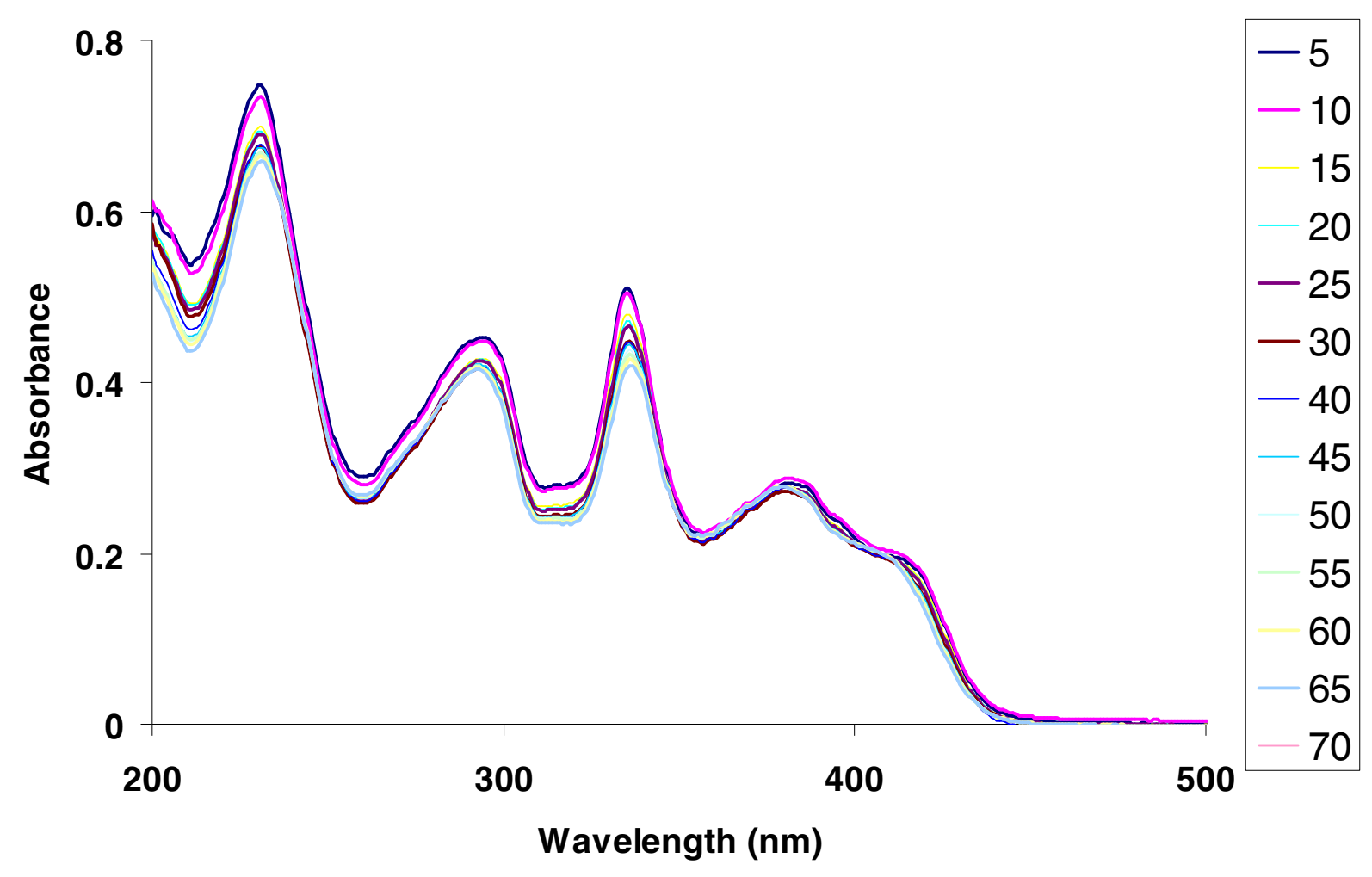

Figure 32. Absorption spectra of 1 in cyclohexane $\left(1 \times 10^{-5} \mathrm{M}\right)$ measured at various temperatures in the range of +5 to $+70{ }^{\circ} \mathrm{C}$. 


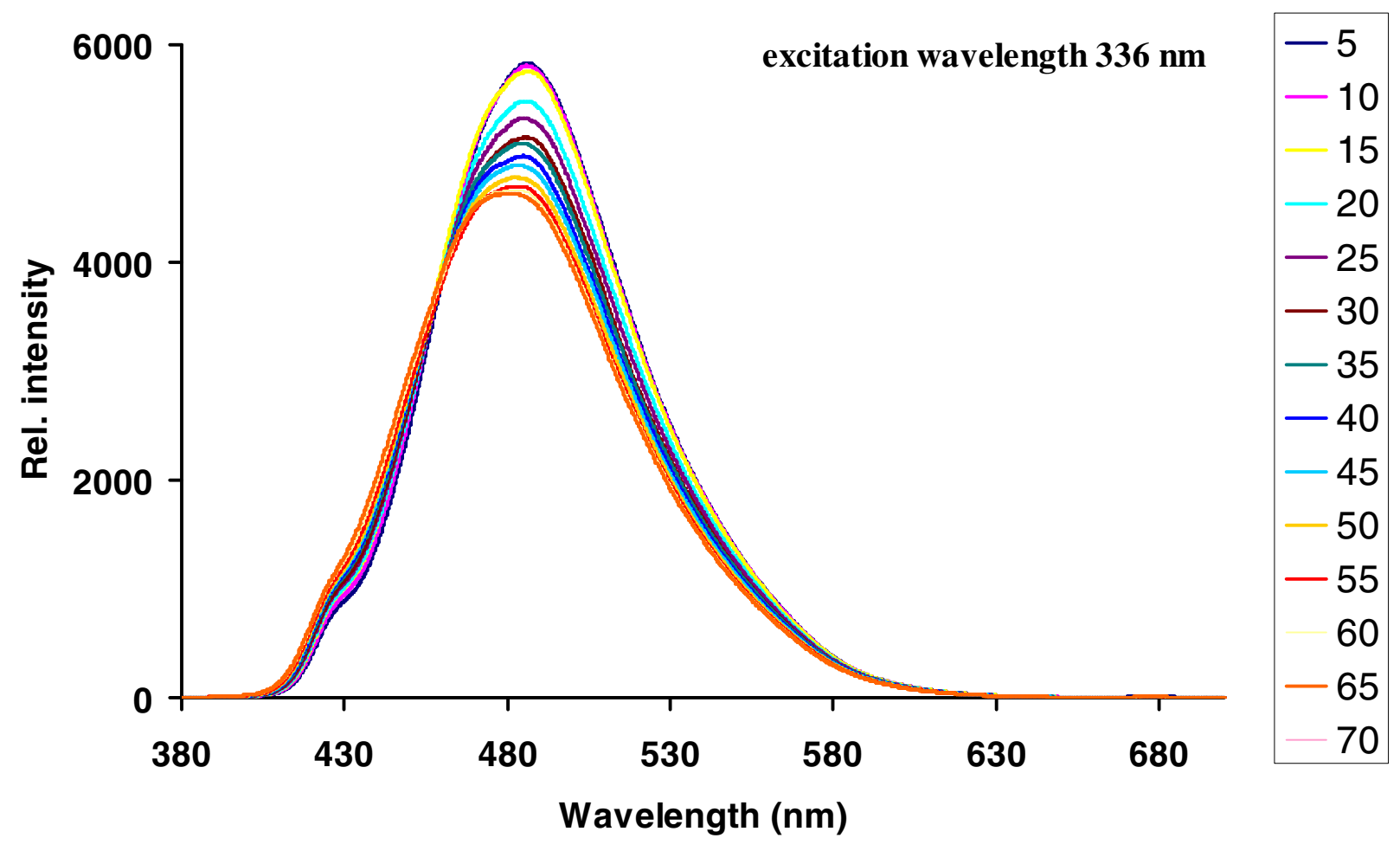

Figure 33. Fluorescence emission spectra of 1 in cyclohexane $\left(1 \times 10^{-5} \mathrm{M}\right)$ measured at various temperatures in the range of +5 to $+70{ }^{\circ} \mathrm{C}$. 